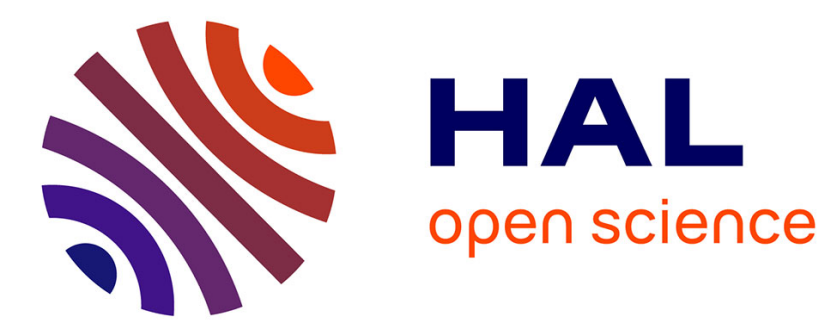

\title{
Political self-serving bias and redistribution
}

Bruno Deffains, Romain Espinosa, Christian Thöni

\section{To cite this version:}

Bruno Deffains, Romain Espinosa, Christian Thöni. Political self-serving bias and redistribution. Journal of Public Economics, 2016, 134, pp.67-74. 10.1016/j.jpubeco.2016.01.002 . halshs-01634208

\section{HAL Id: halshs-01634208 \\ https://shs.hal.science/halshs-01634208}

Submitted on 14 Nov 2017

HAL is a multi-disciplinary open access archive for the deposit and dissemination of scientific research documents, whether they are published or not. The documents may come from teaching and research institutions in France or abroad, or from public or private research centers.
L'archive ouverte pluridisciplinaire HAL, est destinée au dépôt et à la diffusion de documents scientifiques de niveau recherche, publiés ou non, émanant des établissements d'enseignement et de recherche français ou étrangers, des laboratoires publics ou privés. 


\title{
Political Self-Serving Bias and Redistribution
}

\author{
Bruno Deffains;, Romain Espinosa ${ }^{\dagger}$ and Christian Thöni ${ }^{\ddagger}$
}

January 19, 2016

\begin{abstract}
We explore the impact of the self-serving bias on the supply and demand for redistribution. We present results from an experiment in which participants decide on redistribution after performing a real effort task. Dependent on individual performance, participants are divided into two groups, successful and unsuccessful. Participants' success is exogenously determined, because they are randomly assigned to either a hard or easy task. However, because participants are not told which task they were assigned to, there is ambiguity as to whether success or failure should be attributed to internal or external factors. Participants take two redistribution decisions. First, they choose a supply of redistribution in a situation where no personal interests are at stake. Second, they choose a redistributive system behind a veil of ignorance. Our results confirm and expand previous findings on the self-serving bias: successful participants are more likely to attribute their success to their effort rather than luck, and they opt for less redistribution. Unsuccessful participants tend to attribute their failure to external factors and opt for more redistribution. We demonstrate that the self-serving bias contributes to a polarization of the views on redistribution.
\end{abstract}

JEL codes: K10, H3.

Keywords: Redistribution, self-serving bias, experimental, veil of ignorance, polarization

Acknowledgments We thank the editor, Tim Cason, and two anonymous referees for their very constructive remarks. We are also grateful to the participants of the annual congresses of the European Association of Law and Economics (2014, Aix-en-Provence, France), the Louis André Gérard Varet (2015, Aix-en-Provence, France) and the Association Française de Sciences Economiques (2015, Rennes, France). We are also indebted to Stefan Voigt, Jerg Gutmann and the members of the Institute for Law and Economics of Hamburg for their helpful comments. Valuable help and comments by Deborah Kistler and Ismael Rodriguez-Lara are gratefully acknowledged.

\footnotetext{
*Université Paris 2 Panthéon-Assas CRED (TEPP), Institut Universitaire de France and University of Liverpool, School of Management, bruno.deffains@u-paris2.fr

†Université Paris 2 Panthéon-Assas CRED (TEPP), romain.espinosa@u-paris2.fr

‡University of Lausanne, christian.thoeni@unil.ch
} 


\section{Introduction}

Political polarization has been recognized as a challenge for finding political consensus on social and economic issues. Keefer \& Knack (2002) argue that polarization increases legal uncertainty and thereby hinders growth. Alt \& Lassen (2006) provide evidence for higher variations in political business cycles in politically more polarized countries. Other studies have concluded that polarization reduces the likelihood to obtain broad consensus for policy changes and increase collective decision-making costs (Alesina \& Drazen (1991), Rodrik (1999)). What makes societies polarized? Sunstein (2011) emphasizes the role of groups in unifying their members' views with respect to a shared political agenda, which results in stronger polarization across groups. In this article we provide evidence that the experience of success and failure contributes to the polarization in political views.

Our work focuses at a particular domain of social consensus, namely the degree of redistribution between rich and poor members of the society. The recent resurgence of inequalities in democratic countries has led to a renewed interest in the questions of redistribution. ${ }^{1} \mathrm{~A}$ great body of research has sought to understand the factors driving the demand and the supply of redistribution. ${ }^{2}$ Both empirical (Alesina \& Angeletos 2005) and experimental works (Frohlich et al. 1987) have documented the heterogeneity of preferences regarding redistribution. Our research goes one step further, showing that views on redistributive systems are not only shaped by individual preferences, but also malleable by economic experience. In an experimental setting we demonstrate that having been successful in a real effort task makes participants less likely to redistribute income between two other participants, and less likely to opt for redistributive systems behind a veil of ignorance. Unlike studies using eliciting views about redistribution in field settings we can randomly assign participants to the success and failure condition.

Our analysis builds on previous works on the self-serving bias (SSB hereafter). Theories about the SSB postulate that individuals show a tendency to attribute their failure to situational factors, and their success to their own dispositions. ${ }^{3}$ In other words, the SSB claims that, when an individual succeeds at a task, she tends to congratulate herself for her efforts, while she is more prompt to blame the situation when she fails. The SSB predicts therefore a tight relationship between wealth and the perception of the causes of poverty: wealthier individuals are more likely to believe that they deserve their wealth. Considering the above discussion, this might have two effects on the political market. First, the self-serving bias may affect voters whenever they believe that they are successful in life: because people are not willing to recognize that their success is due to random events, they are more likely to support low tax rates. Second, the SSB might also be at play on the supply side of the political market: when deciding on redistribution, politicians are also influenced by their own

\footnotetext{
${ }^{1}$ Various recent works have documented this phenomenon (World: Atkinson (2003), Piketty \& Saez (2006); US: Piketty \& Saez (2003); Germany: Dustmann et al. (2009)).

${ }^{2}$ The literature has investigated egoistic concerns Corneo \& Grüner (2002), Milanovic (2000), altruistic motivations Fong (2001), Boarini \& Le Clainche (2009), social considerations and future perspectives Keely \& Tan (2008).

${ }^{3}$ Miller \& Ross (1975) describe the SSB as "[... people indulge both in self-protective attributions under conditions of failure and in self-enhancing attributions under conditions of success". See also Mezulis et al. (2004) for a recent meta study. For applications in the economic literature see e.g. Babcock et al. (1995), or Babcock \& Loewenstein (1997).
} 
experience, and, thus, exposed to the SSB. In this work, we investigate both dimensions of redistribution. On the one hand, we explore how participants are affected by the SSB when they decide redistribution for other individuals, having no personal interests at stake (supply side). On the other hand, we analyze how participants' preferences toward redistribution are modified by the SSB when they must decide for a redistribution rule that will affect their unknown future own payoffs (demand side).

In accordance with the literature on the SSB we find that succeeding or failing in a task gives rise to systematically different attributions and subsequent redistribution decisions. These findings suggest that increased inequality might have a particularly strong impact on polarizing views about redistribution. Rich people do not only oppose redistribution because they expect to be net payers, but also because the SSB systematically shifts their fairness principles. Likewise, poor people favor redistributive taxation not only because they expect financial gains, but also because the SSB leads them to shift the blame for their situation to external factors. Taken together this makes it difficult to reach a consensus and is likely to increase political tensions across different strata of the society.

The rest of the paper is organized as follows. In Section 2 we discuss previous experiments on redistribution and the veil of ignorance. Section 3 describes the experiment and the predictions. In Section 4 we present the results, and Section 5 concludes.

\section{Literature Review}

An early contribution to the experimental literature on redistribution is Frohlich et al. (1987), who investigate the choice of redistributive systems behind a veil of ignorance ${ }^{4}$, focusing on the democratic process, where participants discuss the options until they reach an unanimous decision. They find support for a redistribution scheme that maximizes the average income with a floor constraint. Later work focuses on individual choices for redistributive systems and documents heterogeneity in redistributive preferences. Some studies argue that redistribution is mainly determined by self-interest (Hoffman \& Spitzer (1985), Durante et al. (2014), Ubeda (2014), Rodriguez-Lara \& Moreno-Garrido (2012)), while other stress the role of social preferences (Tyran \& Sausgruber (2006), Ackert et al. (2007), Schildberg-Hoerisch (2010), Balafoutas et al. (2013)). Klor \& Shayo (2010) study the effect of group identity on redistribution and show that subjects tend to opt for redistribution which favors their group. Eisenkopf et al. (2013) analyze redistribution in a setting of unequal opportunities and find preferences for redistribution to be similar as in a setting where only risk affects the outcome. Gerber et al. (2013) conduct an experiment where they vary the 'thickness' of the veil of ignorance. Participants either (i) know nothing, (ii) have a noisy signal about their productivity, or (iii) have full information about their productivity. They show that the level of redistribution is decreasing in the level of information.

While these studies typically measure preferences for redistribution before the realization

\footnotetext{
${ }^{4}$ The experimental literature has made an extensive use of the veil of ignorance to analyze the preferences for redistribution net of selfish interests. The political economy literature has distinguished between two versions of the veil of ignorance. According to Rawls, individuals should ignore everything they now about their position, whereas Buchanan's version of the veil requires only uncertainty about future outcomes (see e.g. Voigt (2015) for an overview.)
} 
of income, Frohlich \& Oppenheimer (1990), Cabrales et al. (2012), Cappelen et al. (2007), and Großer \& Reuben (2013) investigate preferences for redistribution contingent on economic experience. Close to our work is Kataria \& Montinari (2012), who report results from an unequal opportunity treatment, where participants earn a payoff which partly depends on luck and partly on effort. After the realization of profit participants votes on tax rates. In our design we combine the two approaches: we start with the realization of economic profits and measure the effect of redistribution choices affecting only the allocation of the profits of future economic activities. Furthermore, as opposed to the previous literature we choose a design in which there is a high degree of ambiguity as to the causes of success or failure.

All the papers discussed so far focus on the choices of subjects who are directly affected by the redistributive transfers. In contrast, Konow (2000) studies the behavior of subjects who are not directly affected by the redistribution. He shows that these 'disinterested dictators' act according to the accountability principle, i.e. they are more likely to reward individuals based on their efforts, and to compensate them for back luck. Our design allows to investigate redistributive preferences in situations where the subject is not directly involved (supply of redistribution), and when the subject is directly affected (demand for redistribution). The distinctive feature which distinguishes our experimental design from the previous literature is that instead of measuring preferences for redistribution we exogenously manipulate the participants' experience of success or failure and measure the effect on redistributive preferences.

\section{The Experiment}

Our experiment explores the potential consequences of the self-serving bias on redistribution. Our protocol aims at generating a self-serving bias among participants, and capturing the effects of this bias on both the supply of and the demand for redistribution.

\subsection{Design}

The experiment started with subjects earning money in a real effort task. The purpose of this task was to allocate the status of either 'overachiever' (to the subjects with an above median performance among the subjects in a session), or 'underachiever' (to the remaining subjects). This stage was followed by a manipulation check. After that we elicited our two main measures of interest. First, subjects played the Disinterested Dictator Game (DGG), providing us with a measure of supply of redistribution. Second, we conducted the Redistribution System Game (RSG) as a measure for the demand for redistribution. All interaction was anonymous and computerized. We used z-tree (Fischbacher 2007) to program the interface, and ORSEE (Greiner 2015) for recruitment. ${ }^{5}$

Real Effort Task. The real effort task consisted of a simple task of counting the ones in lines of binary digits. The screen contained 20 to 25 lines, with four to thirteen digits each. Subjects had to indicate the number of ones occurring in each line. There were five

\footnotetext{
${ }^{5}$ See online appendix E for the instructions and screen shots.
} 
consecutive screens and there was a time limit of 25 seconds per screen. Correct answers were rewarded by a certain number of tokens, depending on the condition they were assigned to. Half of the subjects were randomly assigned to the hard condition, the other half to the easy condition. The maximum number of tokens was identical in both conditions. However, the tasks were designed such that it was very unlikely that a subject in the hard condition would earn more tokens than a subject in the easy condition. After completion of the five screens we used the number of tokens earned in the real effort task to perform a median split of the subjects within a session. Subjects who earned more tokens than the median were told that they performed above median (in the article we label them as overachievers), the other subjects were told that they performed below median (underachievers). The fact that the difficulty of the two tasks was sufficiently different ensured that the allocation of the task determined whether a participant was an over- or underachiever. Any differences between over- and underachievers in the DDG or the RSG must then be caused by the allocation of the task, and not by self selection of subjects into treatment. ${ }^{6}$

Subjects were aware of the procedures. In the instructions we informed them that they could be assigned either to an easy or to a hard task with equal probability. Participants were also told that the maximum possible earnings were the same in both tasks. However, at no point in the experiment participants were told which task they were assigned to. While the two tasks clearly differed in difficulty, even the easy task was designed such that none of the participants managed to solve it perfectly, given the time limit. In addition, participants could not observe other participants' tasks. Consequently, participants were unable to deduce which task they were actually assigned to.

After the completion of the real effort task, participants were informed whether their performance was above or below the median. This information was followed by a manipulation check. Subjects answered six questions as to which extent they believed that their relative achievement (success or failure) was due the following factors: (i) the task's difficulty (Diff), (ii) the introduction of the exercise (Intr), (iii) the clearness of the exercise (Clear), (iv) their effort (Eff), (v) their will (Will), and (vi) their attention and focus (Focus). The first three questions identify situational factor, the last three questions individual factors.

Disinterested Dictator Game. For the DDG two participants (the 'targets') were randomly selected among all participants of the session. ${ }^{7}$ The remaining participants (the "disinterested dictators') were informed about the difference between the two targets' incomes of the real effort task. The disinterested dictators had then the possibility to redistribute tokens from the wealthier to the poorer target. All participants were told that the decision of one disinterested dictator would be randomly selected and implemented. Participants

\footnotetext{
${ }^{6}$ In the two first sessions (STANDARD sessions hereafter) four subjects in hard condition managed to become overachievers. Results from these sessions might be influenced by selection. In the results section we will show that our results remain the same if we exclude these two sessions. For the remaining sessions we increased the difference in the difficulty between hard and easy, and we observed a perfect separation. We will refer to the latter as GAP-sessions. For a comparison of the two versions see online appendix C.

${ }^{7}$ In order to ensure comparability among our sessions, the selection process was set as follows. First, we randomly selected the first target. Second, we computed the difference of tokens between the first target and the remaining participants. We then selected a participant such as to have a difference of tokens equal to twenty (or, if there was no exact match, as close to twenty as possible).
} 
were also explicitly told that redistribution would concern only the two targets, and that all others would not be affected by any redistribution mechanism in this task. ${ }^{8}$ Prior to the decision, disinterested dictators were reminded that targets may have faced different tasks. After every disinterested dictator made her choice, one redistribution proposal was randomly selected, and implemented. Disinterested dictators received their payoff from the real effort task, while targets received their real effort task payoff corrected for redistribution. Finally the participants were informed about their final payoff. Importantly, the information participants receive did not allow to infer any redistribution decision of other dictators.

We refer to this game as the Disinterested Dictator Game, because the dictator has the power to redistribute, but-different from the dictator game-does not have his own profit at stake. The game is also different from the so-called third party dictator game (Fehr \& Fischbacher (2004)), in which the classic dictator game is enriched by a third party who can punish the dictator. A game similar to ours is presented by Konow (2000), who studies the accountability principle. Konow investigates the redistribution choice of a dictator who is either exterior to the real effort task and has no stake in the redistribution, or who participates to the game and has direct stakes in the redistribution. Konow refers to the two treatments as the Benevolent Dictator Treatment and the Standard Dictator Treatment. In our case, dictators have taken part in the real effort task but have no stake in redistribution. Previous works in the literature, such as Durante et al. (2014), also used disinterested decision-makers to investigate redistribution decisions net of selfish interests.

Redistribution System Game. For the RSG participants were given new instructions. In these instructions, participants were told that they were going to be matched into groups of four, and that they were going to perform another series of real effort tasks that were substantially different from what they did in the beginning of the experiment. Participants were also informed that they were going to earn tokens in these real effort tasks, but that their payoffs would also be affected by random shocks, which could be either payoff increasing or payoff decreasing. Finally, the instructions said that, after each task and after each shock, redistribution was going to occur within each group according to the group's redistribution system.

Participants were also informed that, prior to the real effort game, they would vote on redistribution systems. We presented three canonical redistribution systems to the participants. The libertarian system leaves each participant with her after-shock payoff (no redistribution). The egalitarian system sums up all individual after-shock payoffs within the group, and redistributes the sum in equal shares to the group members (full redistribution). Finally, the social-liberal system sums up all individual after-shock payoffs within the group, and redistributes the sum proportionally to the individual pre-shock payoffs (effort-based redistribution). Subjects could indicate their preferences for the three systems in the vote, i.e., apart from the 'pure' systems, they could also implement a mixture of the systems. To aid understanding the instructions contained a table showing how each redistribution system affects their final payoffs for given pre-shock and after-shock payoffs. Before turning to the vote, we presented the participants with control questions to ensure that the three redistribution principles were well understood. In four of the six sessions the control questions were

\footnotetext{
${ }^{8}$ Figure E1 in the appendix shows a screen shot of this stage.
} 
three general statements about the redistribution systems and participants had to indicate whether they were correct or not (BASELINE sessions, for the instructions see Appendix E2). In these sessions there are two sources of ambiguity: participants do not know the task they will have to perform and they receive no specific information about the random shock. In the two remaining sessions we eliminated the ambiguity about the random shock and informed the participants that the shock would change their income by $-5,-4, \ldots, 4,5$ tokens with equal probability (EXTENDED sessions, instructions in Appendix E3). Furthermore we implemented different control questions, in which participants were asked to compute hypothetical after-redistribution payoffs for a given set of pre-redistribution payoffs of the four group members. The examples comprised four redistribution systems: 100\% libertarian, 100\% egalitarian, 100\% social-liberal, and 50\% libertarian 50\% social-liberal (Appendix Figure E2). ${ }^{9}$

After the presentation of the redistribution systems, participants were asked to assign weights $w_{i}$ between 0 and 10 to each of the three redistribution systems. Participants were told that one group member's set of choices would be randomly chosen and implemented for the group. Given three weights $w_{1}, w_{2}$ and $w_{3}$ we computed a triplet of relative weights $v_{i}=\frac{w_{i}}{w_{1}+w_{2}+w_{3}}, i=1,2,3$. For each of the real effort tasks a participant's final payoff is equal to $v_{1} \%$ (resp. $v_{2} \%$ and $v_{3} \%$ ) of the payoff that she would have earned under the canonical system 1 (resp. 2 and 3).

After the vote and the determination of the redistribution system participants were informed about the redistribution system selected for their group. A screen displayed the composition in terms of percentages of the three canonical system. After that, participants proceeded with the real effort tasks. They had to read a short text (approx 140 words) and count the number of misspelled words. The individual (pre-shock and pre-redistribution) profit of the task was equal to the 20 tokens minus four times the absolute difference between the reported number of mistakes and the real number of mistakes in the text. After each real effort task participants learned their initial profit, their profit after the shock, and their final profit (including redistribution). Then participants were asked (1) whether they were satisfied with the implemented redistribution system, and (2) whether they felt reinforced in their original choice. The experiment ended after four real effort tasks.

The RSG is inspired by the experiment reported in Frohlich \& Oppenheimer (1990), where subjects choose a redistribution system without knowing the nature of the task they are about to perform. Once a redistribution system has been selected, subjects are given a series of texts to correct (spelling mistakes). The choice of redistribution systems follows Gerber et al. (2013).

\subsection{Hypotheses}

Our experimental protocol aimed at investigating how the self-serving bias may impact the supply and the demand of redistribution. We create a situation in which participants are aware of their relative status in the population, but have limited information about whether they should attribute the outcome to luck or effort. The real effort task in the beginning

\footnotetext{
${ }^{9}$ Using control questions presumably enhances subjects' understanding of the mechanisms, but it might have the disadvantage that the experimenter has to pick specific actions of the game as examples, which might influence subsequent behavior, see Roux \& Thöni (2015).
} 
of the experiment creates two kinds of participants: those who performed better than the median participant (overachievers), and those who performed worse than the median participant (underachievers). We hypothesize that this manipulation induces a self-serving bias among participants: overachievers tend to attribute the outcome to their efforts, whereas underachievers tend to attribute the outcome to bad luck. The Disinterested Dictator Game measures the impact of this change of the perceptions of causality on the supply of redistribution towards third parties. Indeed, as Konow (2000) showed, people decide on redistribution according to the accountability principle, i.e. they reward people proportionally to their level of effort. By affecting the perception of the role played by effort in the final outcome, we expect the self-serving bias to affect the supply of redistribution: overachievers (underachievers) will be more likely to believe that efforts (random factors) determine success, and will therefore be less (more) likely to redistribute. Because decision-makers profits are not affected by redistribution, our protocol allows us to isolate how the redistribution is changed by the perception of the causes of success in the absence of selfish interests. ${ }^{10}$ Our prediction with regard to the DDG is:

Prediction 1 Overachievers will redistribute less than underachievers.

In the Redistribution System Game participants are asked to express their preferences over three redistribution systems. Unlike in the first game, participants' redistribution decisions at the beginning of the second game are designed to affect their own future (unknown) payoff. The ex-ante choice about the redistribution systems ensures that participants express their demand for redistribution behind a veil of ignorance, i.e., not knowing the nature of the real effort task. ${ }^{11}$ Following the same argument as for prediction 1, if the self-serving bias changes one's perception of the determinants of success, overachievers should be more likely to believe that their future payoffs will be determined by their efforts than underachievers, and therefore express a lower demand for redistribution.

When taking a decision in the RSG game, participants presumably consider three factors that affect their future revenue: their level of effort, their ability in the (unknown) task, and the random shocks. The first factor is obviously endogenous, while the two latter are exogenous. The two exogenous factors result in uncertainty and risk. First, participants face uncertainty regarding the nature of the task they are about to perform. Second, they face risk concerning the shocks that they know to happen after each task. The libertarian system corresponds to a situation without insurance. On the opposite, the egalitarian system insures against both risk and uncertainty: if an individual faces a task at which he/she is very bad, he/she will receive transfers from other participants more capable at this task. Moreover, in the egalitarian system, shocks are fully compensated. However, the egalitarian system comes at a cost, because it generates incentives to free ride. The social-liberal system stands in-between: it redistributes according to the pre-shock payoff, which is determined by the participants' abilities and effort, but not by the shocks. Consequently, the social-liberal

\footnotetext{
${ }^{10}$ Note that our experimental design minimizes the focus on the own profit at this stage. The only information participants receive when deciding in the DDG is the difference between the two targets' payoffs. They have no information about absolute payoffs, not even their own payoff.

${ }^{11}$ Our protocol is close to Buchanan's version of the veil of ignorance. (See footnote 4) We get rid of immediate egoistic interests by putting uncertainty on future outcomes.
} 
system provides an insurance against risk, but not against uncertainty.

Due to the self-serving bias a successful participant is more likely to see the outcome as resulting from his/her own effort than a less successful participant. The self-serving bias is therefore likely to impact the demand for redistribution in cases where causation is not clearly determined. Thus, the self-serving bias should increase the demand for insurance against uncertainty for participants who performed relatively worse, because they expect the nature of the task to play a predominant role in the determination of their payoff. On the other hand, random shocks are clearly exogenous. The self-serving should therefore not have an impact on the demand for insurance against risk.

Three predictions follow from this discussion. First, we expect overachievers to have a stronger preference for social-liberalism than underachievers. Conversely, we anticipate that underachievers will display a stronger demand for the egalitarian system.

Prediction 2A Overachievers will opt for less egalitarianism than underachievers.

Prediction 2B Overachievers will opt for more social-liberalism than underachievers.

In case of the libertarian system things are less clear. If the social-liberal system was not available, then this system would most likely be more preferable to overachievers than underachievers, for the reasons discussed above. However, when all three redistribution systems are available, support for the libertarian system can only be explained if participants prefer some of the risk to be uninsured, i.e., if they are to some extent risk seeking. We do not see an a priori reason why the status of under- or overachiever should systematically affect risk preferences. Our prediction is therefore

Prediction 2C Overachievers and underachievers will not systematically differ in their support for libertarianism.

\section{Results}

We ran six sessions with 24 participants each. All sessions were run in Strasbourg (January and February 2014, July 2015). The sessions lasted about 45 minutes, and participants earned on average 13.66 euro. We present our results in the order in which they were elicited, starting with real effort task, followed by the Disinterested Dictator Game and the Redistribution System Game.

\subsection{Real effort task}

The experiment starts with a real effort task, in which subjects are asked to determine the number of ones in binary sequences. This provides us with a measure for individual performance. The left panel of Figure 1 shows the results of the real effort task. Subjects randomly allocated to the hard task scored on average 19.4 tokens (sd: 4.02), while subjects in the easy task scored 33.6 (sd: 5.25) tokens. Spikes in the figure are standard errors, indicating that the difference between the hard and easy task is highly significant. 
Based on the performance measure we classify our subjects into overachievers (above median performance), and underachievers. In four sessions the hard/easy task was perfectly separating the population, i.e., all participants randomly allocated to the easy task turned out to be overachievers, and vice versa. In the other sessions four participants with the hard task managed to perform better than the median participant, and became overachiever. Consequently, four participants with the easy task became underachiever. Note that our protocol induced the same level of information for both underachievers and overachievers regardless of their original task. It follows that participants were not able to deduce whether they were assigned to the hard or the easy task, such that presumably only the labeling as 'above the median' or 'below the median' affected their attributions. Consequently selfserving bias (SSB) can occur irrespective of the original task a participant was assigned to.

Before looking at the redistribution decisions, we perform a manipulation check to see whether our protocol effectively induced a self-serving bias among participants. To do so, we compare answers to the six questions as to whether subjects attribute their success (or failure) to effort or luck. Comparing the average scores of overachievers and underachievers shows that the former gave systematically higher scores to all questions (see Table 1 in the appendix). To compare the relative weight of situational factors to the factors related to effort (individual), we define a measure Fatalism as the ratio between the sum of the scores for the three situational factors and the sum of the scores for the individual factors. The middle panel of Figure 1 shows the results. We find a clear and significant difference in Fatalism between the two groups: With a ratio of 1.30 underachievers put a higher relative weight on situational factors than overachievers (0.94). The difference is significant at $p=.003$ (two-sample t-test). ${ }^{12}$ To conclude, the experience of being an under- or overachiever systematically affects the way participants attribute the outcome to internal and external factors. While overachievers tend to emphasize their own contribution, underachievers tend to focus on external factors, i.e., develop a more fatalist attitude. We see this as a clear indication for a self-serving bias. In a next step we investigate whether the differences between over- and underachievers affect redistribution decisions.

\subsection{DDG: Supply of Redistribution}

Recall that in the disinterested dictator game redistribution affects only targets' payoffs. Dictators were specifically told that no redistribution would affect their own payoff in this game. Since we have some variation in the differences between the two targets' profits across sessions we calculate the percentage of the payoff difference to be redistributed form the richer to the poorer target. Zero corresponds to leaving the incomes unchanged, while reallocating 50 percent of the difference means that the two profits are equalized. Overall we observe a redistribution of 37.4 percent; 17.4 percent of the subjects do not redistribute at all, while 41.7 percent of the subjects implement a solution which equalized payoffs.

Prediction 1 links a person's status after the real effort task to the supply of redistribution. The right panel of Figure 1 shows the average redistribution percentage chosen

\footnotetext{
${ }^{12}$ The results are very similar if we consider only the GAP sessions (1.21 vs. 0.90); and the difference remains significant $(p=.012)$.
} 

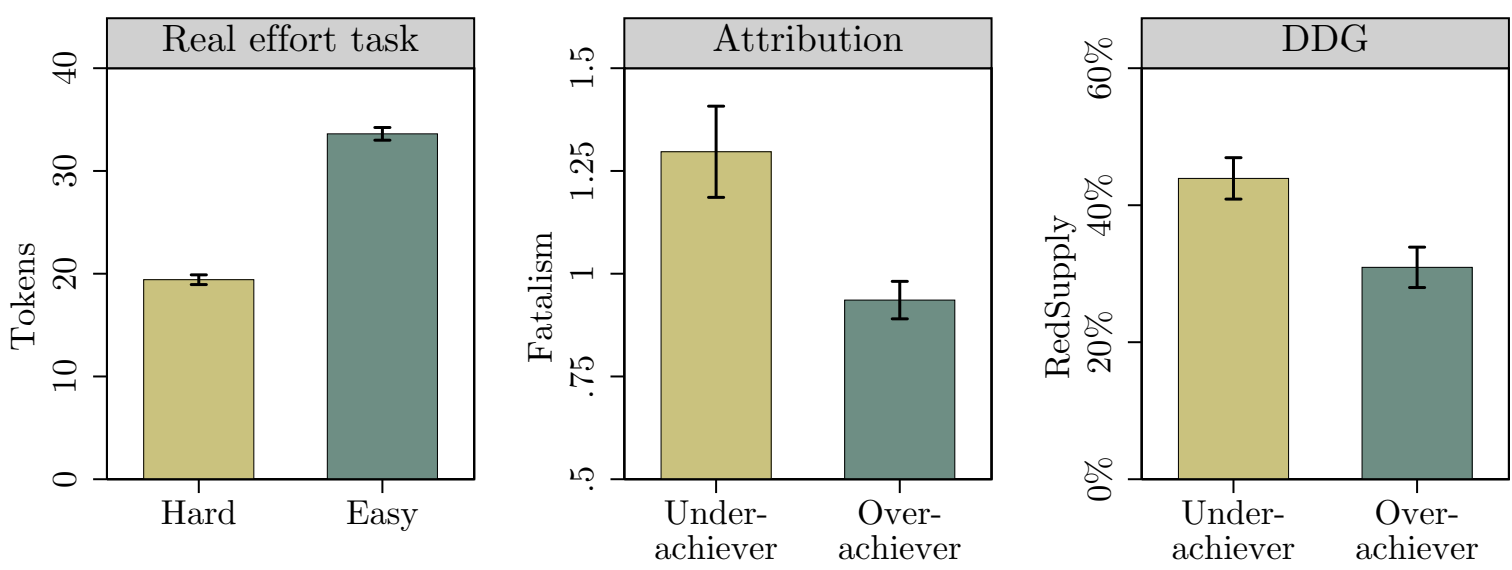

Figure 1: Left panel: Average number of tokens earned in the hard and easy real effort task. Middle panel: Levels of Fatalism, defined as the ratio between external and internal factors, for over- and underachievers. Right panel: Percentage redistributed in the disinterested dictator game. Spikes show standard errors.

by underachievers and overachievers (RedSupply). The difference is substantial and significant: Underachievers redistribute 43.9 percent while overachievers redistribute 30.9 percent $\left(p=.003\right.$, two-sample t test).$^{13}$ In the online appendix we provide additional analyses to check the robustness of our results on Fatalism and the redistribution decision. First, we perform a permutation test (two-sided $p=.001$ and $p=.001$, see Figures B1 and B2 in the online appendix); second we run OLS estimates controlling for individual characteristics gender, political orientation, age, and the practice of competitive sport, as well as a dummy for the GAP sessions (online appendix Table A1). ${ }^{14}$ The effect of overachiever is highly significant in all specifications, while none of the other covariates seem to explain the redistribution decision. This leads to our first result:

Result 1 Overachievers redistribute less money from the rich to the poor target than underachievers.

\subsection{RSG: Demand for redistribution}

We now turn to the analysis of the preferences over the redistribution systems in the second game. Because participants were told that the real effort tasks of the second game would be substantially different from the first real effort task, they were a priori not able to predict their productivity and their relative abilities and in the task. In this regard, the decisions made at the beginning of the second game are taken behind a veil of ignorance. As opposed

\footnotetext{
${ }^{13}$ The effect size is almost identical if we consider only the GAP sessions (42.2 percent vs. 29.9 percent); and the difference remains significant $(p=.015)$.

${ }^{14}$ Our results are also robust when we cluster standard errors on the session level. Because of the small number of clusters, we implemented wild bootstrapping to obtain robust $p$-values such as suggest by Cameron \& Miller (2015). See model 5 in Table A2 of the online appendix for the results.
} 


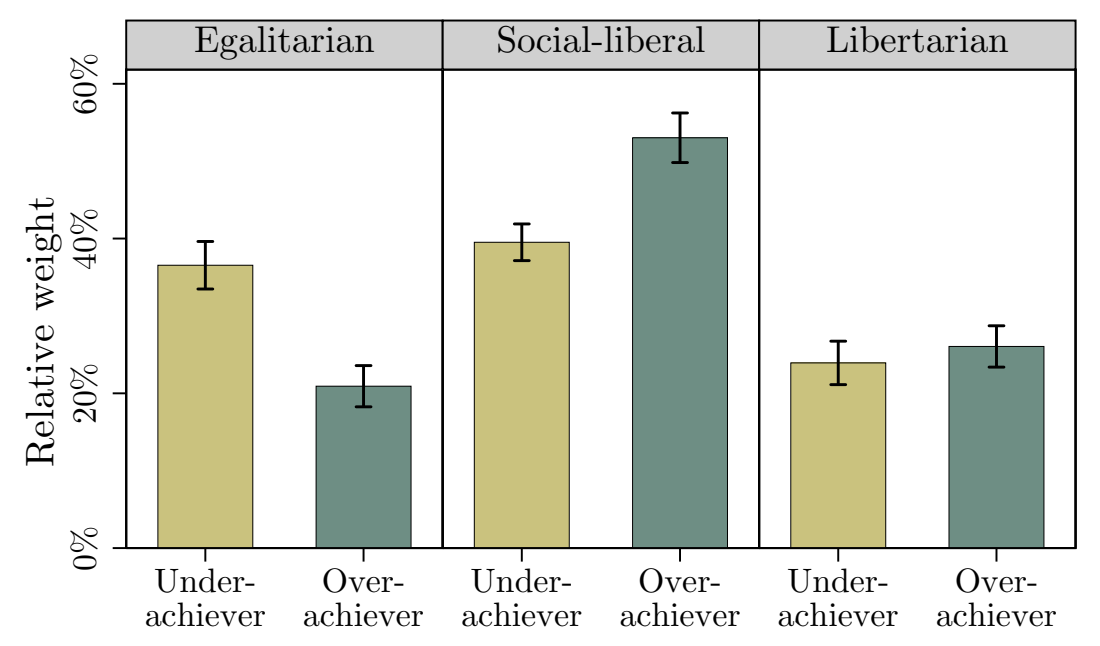

Figure 2: Results from the Redistribution System Game. Bars show average relative weight given to the respective redistribution system. Spikes show standard errors.

to the DDG, redistribution now affects the own payoff, which means that decisions can be interpreted as demand for redistribution.

The choice of a redistribution system is measured by the importance levels indicated for each of the three canonical systems. For the following analysis we normalize the scores such that the value represents a percentage. ${ }^{15}$ Overall the social-liberal system (SocialLib) is clearly the most popular among our participants, with an average relative weight of 46.3 percent, followed by the egalitarian system (Egal, 28.7 percent), and the libertarian system (Libert, 25.0 percent). ${ }^{16}$

Regarding our predictions we find that overachievers' preferences over redistribution systems are systematically different from those of underachievers. Figure 2 illustrates the main results. Most pronounced are differences in the support for the egalitarian system, which receives on average 36.6 percent of the relative weight among underachievers and only 20.9 among overachievers $(p<.001$, two-sample t test). Most of the difference is offset by a stronger support for social-liberalism, which is more popular among overachievers (53.0 percent), than among underachievers (39.5 percent, $p<.001)$. For the libertarian we find slightly more support among overachievers (26.1 percent) than among underachievers (23.9 percent). The difference is, however, far from significant $(p=.585) .{ }^{17}$

We ran a series of OLS estimations to explain support for the redistributive systems by a participant's status and controls (for details see online appendix A, Tables A3 to A5).

\footnotetext{
${ }^{15}$ Results with the absolute weights are very similar (see Table 1). Absolute weights are labelled absLibert, absSocialLib, and absEgal.

${ }^{16}$ The results from the two sessions with the EXTENDED protocol are similar to the results of the four sessions in BASELINE. The weight of SocialLib is almost identical (46.5 percent vs. 45.8 percent , $p=.878$ ); Libert receives somewhat stronger support in the BASELINE sessions (29.7 percent vs. 22.6 percent, $p=.085)$. For details see online appendix D.

${ }^{17}$ The results for the comparison between over- and underachievers are very similar in BASELINE and EXTENDED. For example, the support for SocialLib increases from 40.0 percent to 52.9 percent in BASELINE and from 38.4 percent to 53.3 percent in EXTENDED. See online appendix D for details.
} 
Across a number of specifications we confirm the main result that overachievers opt for more SocialLib and less Egal, and there is no significant effect for Libert. Furthermore, male participants tend to exhibit stronger (weaker) preferences for SocialLib (Egal) than female participants. Among the remaining controls we find that political orientation is strongly related to the support for Libert and Egal. Participants who indicate that they are politically closer to the right opt for more Libert and less Egal. ${ }^{18}$ In the estimates with controls we find that the sessions where we provided more information about the shock (EXTENDED) tends to increase the support for Libert and decrease the support for Egal.

Taken together the evidence clearly supports our predictions $2 \mathrm{~A}$ to $2 \mathrm{C}$ : The self-serving bias affects the demand of insurance against uncertainty, but not the demand of insurance against risk. Underachievers are more likely to prefer full insurance than overachievers (egalitarianism), while overachievers display a stronger preference for a system that insures only against risk.

Result 2 Overachievers have a stronger preference for the social-liberal system than underachievers, who, in turn, have a stronger preference for egalitarianism. We find no significant differences in the support for the libertarian system.

\section{Conclusion}

Our paper investigates the consequences of the self-serving bias on redistribution choices. To do so, we run an experiment in which we induce a self-serving bias among participants. To isolate the effects of the self-serving bias from selfish interests, we make participants choose on the level of redistribution in a disinterested manner or behind a veil of ignorance. This allows us to assess the impact of the self-serving bias on both the supply and the demand of redistribution.

We conclude on two far-reaching results. We show that participants with a good (resp. bad) relative success status display a lower (higher) supply of redistribution, because they are on average more (less) likely to believe that their outcome result from their efforts compared to participants with a bad (good) relative success status. Second, we show that the self-serving bias also affects the demand of redistribution in the same manner, i.e., by reducing (resp. increasing) the demand for redistribution for relatively successful (resp. less successful) participants.

Our findings have significant implications for political debates on redistribution, as the self-serving bias polarizes both the supply and the demand of redistribution. The increase in polarization resulting from the self-serving bias rises numerous questions. First of all, it asks a normative question: Is the increased polarization of the political debate necessary

\footnotetext{
${ }^{18}$ In the instructions and on the screen we used the same labels for the three systems as in this article. We cannot therefore rule out the possibility that the preferences for the libertarian system by the rightist participants are driven by a (to them) appealing label. However, given the random assignment of the easy and hard task, political orientation should be identically distributed across groups (overachievers vs. underachievers). Indeed we observe no significant difference between the two groups (two-sample t-test: $p=.595)$. It follows that the lack of significance of the overachiever status cannot be attributed to labelling issues.
} 
harmful for society? Previous works in the literature presented in the introduction tend to indicate that political polarization has negative effects on economic growth. One could, however, also postulate that the increased polarization might strengthen the competition on the political market by forcing parties to propose different platforms. Even considering that the heterogeneity of preferences is not necessary harmful for the system, it is however legitimate to wonder whether the increase of polarization resulting from the self-serving bias is welfare enhancing. This increase of polarization seems indeed to result from partly contingent economic experience. In other words, the self-serving bias might generate volatile variations in the political preferences toward redistribution. Although society might benefit from divergence of opinions, collective decision-making may suffer from such variations. Third, considering that the self-serving bias might create unnecessary polarization, a legitimate question is whether institutions should seek to unbias citizens. The literature on nudges argues that society might benefit from making use of psychological mechanisms as policy tools (Thaler \& Sunstein 2008). Two questions follow. First, is it legitimate for the government to unbias citizens regarding redistribution, given that the government has its own -maybe also biased- view about redistribution? Second, what is the unbiased amount of redistribution one individual would have wanted if she did not experience her economic condition?

Our experimental approach to induce a SSB with regard to success and failure could be expanded to study a number of interesting questions. First, our protocol aimed at inducing a self-serving bias among participants by creating two groups of individuals: over- and underachievers. The dichotomous nature of our treatment is an experimental simplification, which is not realistic. Expanding the design to a continuous setting would allow to investigate how the SSB and redistributive choices would react to fine-grained changes in relative performance. Second, it would be interesting to explore the potential of information to unbias the participants and reduce the polarization. One of the least controversial means to unbias individuals might be to disseminate scientific evidence about the relative importance of external and internal factors in the determination of the position in the social hierarchy, such as the degree of intergenerational mobility (Bowles \& Gintis 2002, Chetty et al. 2014). 


\section{Appendix: Summary statistics}

\begin{tabular}{|c|c|c|c|c|c|}
\hline Variable & Source & All Participants & Underachievers & Overachievers & $p$-value \\
\hline Diff & $\mathrm{MC}$ & $\begin{array}{c}3.903 \\
(1.893)\end{array}$ & $\begin{array}{c}3.597 \\
(1.998)\end{array}$ & $\begin{array}{c}4.208 \\
(1.744)\end{array}$ & 0.052 \\
\hline Intr & $\mathrm{MC}$ & $\begin{array}{c}4.604 \\
(1.922)\end{array}$ & $\begin{array}{c}4.472 \\
(2.143)\end{array}$ & $\begin{array}{c}4.736 \\
(1.678)\end{array}$ & 0.412 \\
\hline Clear & $\mathrm{MC}$ & $\begin{array}{l}3.639 \\
(2.295)\end{array}$ & $\begin{array}{l}2.125 \\
(1.695)\end{array}$ & $\begin{array}{l}5.153 \\
(1.758)\end{array}$ & 0.000 \\
\hline Eff & $\mathrm{MC}$ & $\begin{array}{c}3.951 \\
(1.682)\end{array}$ & $\begin{array}{c}3.333 \\
(1.601)\end{array}$ & $\begin{array}{c}4.569 \\
(1.537)\end{array}$ & 0.000 \\
\hline Will & $\mathrm{MC}$ & $\begin{array}{c}4.042 \\
(2.099)\end{array}$ & $\begin{array}{c}2.653 \\
(1.567)\end{array}$ & $\begin{array}{c}5.431 \\
(1.582)\end{array}$ & 0.000 \\
\hline Focus & $\mathrm{MC}$ & $\begin{array}{l}4.993 \\
(1.83)\end{array}$ & $\begin{array}{c}3.917 \\
(1.782)\end{array}$ & $\begin{array}{l}6.069 \\
(1.105)\end{array}$ & 0.000 \\
\hline Fatalism & $\mathrm{MC}$ & $\begin{array}{l}1.116 \\
(.74)\end{array}$ & $\begin{array}{l}1.297 \\
(.942)\end{array}$ & $\begin{array}{l}.936 \\
(.387)\end{array}$ & 0.003 \\
\hline RedSupply & DDG & $\begin{array}{l}.374 \\
(.25)\end{array}$ & $\begin{array}{l}.439 \\
(.246)\end{array}$ & $\begin{array}{l}.309 \\
(.24)\end{array}$ & 0.003 \\
\hline absLibert & RSG & $\begin{array}{l}4.035 \\
(3.545)\end{array}$ & $\begin{array}{c}3.861 \\
(3.562)\end{array}$ & $\begin{array}{l}4.208 \\
(3.544)\end{array}$ & 0.559 \\
\hline absSocialLib & RSG & $\begin{array}{l}7.021 \\
(3.194)\end{array}$ & $\begin{array}{c}6.431 \\
(3.223)\end{array}$ & $\begin{array}{l}7.611 \\
(3.074)\end{array}$ & 0.026 \\
\hline absEgal & RSG & $\begin{array}{c}4.556 \\
(3.747)\end{array}$ & $\begin{array}{l}5.681 \\
(3.626)\end{array}$ & $\begin{array}{l}3.431 \\
(3.544)\end{array}$ & 0.000 \\
\hline Libert & RSG & $\begin{array}{l}.25 \\
(.232)\end{array}$ & $\begin{array}{l}.239 \\
(.238)\end{array}$ & $\begin{array}{l}.261 \\
(.226)\end{array}$ & 0.584 \\
\hline SocialLib & RSG & $\begin{array}{l}.463 \\
(.248)\end{array}$ & $\begin{array}{l}.395 \\
(.201)\end{array}$ & $\begin{array}{c}.53 \\
(.272)\end{array}$ & 0.001 \\
\hline Egal & RSG & $\begin{array}{l}.287 \\
(.255)\end{array}$ & $\begin{array}{l}.366 \\
(.261)\end{array}$ & $\begin{array}{l}.209 \\
(.226)\end{array}$ & 0.000 \\
\hline
\end{tabular}

Table 1: Summary Statistics: mean and standard deviation (in parentheses); $p$-values correspond to bilateral two-group mean-comparison tests. MC stands for Manipulation Check, DDG for Disinterested Dictator Game and RSG for Redistribution System Game. 


\section{References}

Ackert, L. F., Martinez-Vazquez, J. \& Rider, M. (2007), 'Social preferences and tax policy design: Some experimental evidence', Economic Inquiry 45(3), 487-501.

Alesina, A. \& Angeletos, G.-M. (2005), 'Fairness and redistribution', American Economic Review 95(4), 960-980.

Alesina, A. \& Drazen, A. (1991), 'Why are Stabilizations Delayed?', American Economic Review 81, 1170-1188.

Alt, J. E. \& Lassen, D. D. (2006), 'Transparency, Political Polarization, and Political Budget Cycles in OECD Countries', American Journal of Political Science 50(3), 530-550.

Atkinson, A. B. (2003), 'Income Inequality in OECD Countries: Data and Explanations', CESifo Economic Studies 49, 479-513.

Babcock, L. \& Loewenstein, G. (1997), 'Explaining bargaining impasse: The role of selfserving biases', Journal of Economic Perspective 11(1), 109-126.

Babcock, L., Loewenstein, G., Issacharoff, S. \& Camerer, C. (1995), 'Biased judgments of fairness in bargaining', American Economic Review 85(5), 1337-1343.

Balafoutas, L., Kocher, M. G., Putterman, L. \& Sutter, M. (2013), 'Equality, equity and incentives: An experiment', European Economic Review 60, 32-51.

Boarini, R. \& Le Clainche, C. (2009), 'Social preferences for public intervention: An empirical investigation based on french data', Journal of Socio-Economics 38, 115-128.

Bowles, S. \& Gintis, H. (2002), 'The inheritance of inequality', Journal of Economic Perspectives 16(3), 3-30.

Cabrales, A., Nagel, R. \& Rodriguez-Mora, J. V. (2012), 'It is Hobbes, not Rousseau: An experiment on voting and redistribution', Experimental Economics 15, 278-308.

Cameron, A. C. \& Miller, D. L. (2015), 'A practitioner's guide to cluster-robust inference', Journal of Human Resources 50(2), 317-372.

Cappelen, A. W., Hole, A. D., Sørensen, E. Ø. \& Tungodden, B. (2007), 'The pluralism of fairness ideals: An experimental approach', American Economic Review 97(3), 818-827.

Chetty, R., Hendren, N., Kline, P. \& Saez, E. (2014), 'Where is the land of opportunity? The geography of intergenerational mobility in the United States', Quarterly Journal of Economics 129(4), 1553-1623.

Corneo, G. \& Grüner, H. P. (2002), 'Individual preferences for political redistribution', Journal of Public Economics 83, 83-107. 
Durante, R., Putterman, L. \& van der Weele, J. (2014), 'Preferences for redistribution and perception of fairness: An experimental study', Journal of the European Economic Association 12(4), 1059-1086.

Dustmann, C., Ludsteck, J. \& Schönberg, U. (2009), 'Revisiting the German wage structure', Quarterly Journal of Economics 124(2), 843-881.

Eisenkopf, G., Fischbacher, U. \& Föllmi-Heusi, F. (2013), 'Unequal opportunities and distributive justice.', Journal of Economic Behavior and Organization 93, 51-61.

Fehr, E. \& Fischbacher, U. (2004), 'Third-party punishment and social norms', Evolution and Human Behavior 25(2), 63-87.

Fischbacher, U. (2007), 'z-tree: Zurich toolbox for ready-made economic experiments', Experimental Economics 10(2), 171-178.

Fong, C. (2001), 'Social preferences, self-interest, and the demand for redistribution', Journal of Public Economics 82, 225-46.

Frohlich, N. \& Oppenheimer, J. A. (1990), 'Choosing justice in experimental democracies with production', American Political Science Review 84, 461-477.

Frohlich, N., Oppenheimer, J. A. \& Eavey, C. L. (1987), 'Laboratory results on Rawls' distributive justice', British Journal of Political Science 17, 1-21.

Gerber, A., Nicklisch, A. \& Voigt, S. (2013), Strategic choices for redistribution and the veil of ignorance. Hamburg Wiso Working Paper Series 2013/5.

Greiner, B. (2015), 'Subject pool recruitment procedures: Organizing experiments with ORSEE', Journal of the Economic Science Association 1(1), 114-125.

Großer, J. \& Reuben, E. (2013), 'Redistribution and market efficiency: An experimental study', Journal of Public Economics 101, 39-52.

Hoffman, E. \& Spitzer, M. L. (1985), 'Entitlements, rights, and fairness: An experimental examination of subjects' concepts of distributive justice', Journal of Legal Studies 14(2), 259-297.

Kataria, M. \& Montinari, N. (2012), 'Risk, entitlement and fairness bias: Explaining preferences for redistribution in multi-person setting', Working Paper.

Keefer, P. \& Knack, S. (2002), 'Polarization, politics and property rights: Links between inequality and growth', Public choice 111(1-2), 127-154.

Keely, L. C. \& Tan, C. M. (2008), 'Understanding preferences for income redistribution', Journal of Public Economics 92, 944-961.

Klor, E. F. \& Shayo, M. (2010), 'Social identity and preferences over redistribution', Journal of Public Economics 94, 269-278. 
Konow, J. (2000), 'Fair shares: Accountability and cognitive dissonance in allocation decisions', American Economic Review 90(4), 1072-1091.

Mezulis, A. H., Abramson, L. Y., Hyde, J. S. \& Hankin, B. L. (2004), 'Is there a universal positivity bias in attributions? a meta-analytic review of individual, developmental, and cultural differences in the self-serving attributional bias', Psychological Bulletin 130(5), 711-747.

Milanovic, B. (2000), 'The median-voter hypothesis, income inequality, and income redistribution: An empirical test with the required data', European Journal of Political Economy 16, 367-410.

Miller, D. T. \& Ross, M. (1975), 'Self-serving biases in the attribution of causality: Fact or fiction?', Psychological Bulletin 82(2), 213-225.

Piketty, T. \& Saez, E. (2003), 'Income inequality in the united states 1913-1998', Quarterly Journal of Economics 118, 1-39.

Piketty, T. \& Saez, E. (2006), 'The evolution of top incomes: A historical and international perspective', American Economic Review 96(2), 200-205.

Rodriguez-Lara, I. \& Moreno-Garrido, L. (2012), 'Self-interest and Fairness: Self-serving Choices of Justice Principles', Experimental Economics 15, 158-175.

Rodrik, D. (1999), 'Where did All the Growth Go? External Shocks, Social Conflict, and Growth Collapses', Journal of Economic Growth 4(4), 385-412.

Roux, C. \& Thöni, C. (2015), 'Do control questions influence behavior in experiments?', Experimental Economics 18(2), 185-194.

Schildberg-Hoerisch, H. (2010), 'Is the veil of ignorance only a concept about risk? An experiment', Journal of Public Economics 94, 1062-1066.

Sunstein, C. R. (2011), Going to Extremes: How Like Minds Unite and Divide, Oxford University Press.

Thaler, R. H. \& Sunstein, C. R. (2008), Nudge. Improving Decisions About Health, Wealth, and Happiness, Yale University Press, New Haven \& London.

Tyran, J.-R. \& Sausgruber, R. (2006), 'A little fairness may induce a lot of redistribution in democracy', European Economic Review 50(2), 469-485.

Ubeda, P. (2014), 'The Consistency of Fairness Rules: An Experimental Study', Journal of Economic Psychology 41, 88-100.

Voigt, S. (2015), Veilonomics: On the use and utility of veils in constitutional political economy, in L. M. Imbeau \& S. Jacob, eds, 'Behind a Veil of Ignorance?', Vol. 32, Springer International Publishing, pp. 9-33. 


\title{
Online Appendix
}

\section{Political Self-Serving Bias and Redistribution}

\author{
Bruno Deffains, Romain Espinosa, Christian Thöni
}

Journal of Public Economics

\section{A Additional Analyses}

In this section, we present the estimation results of the econometric specifications discussed in the paper. We perform a multivariate analysis of the degree of Fatalism, the redistribution decision in the first game, and the weights of the three redistribution systems in the second game. Our set of explanatory variables includes a gender dummy and the participant's age. Since redistribution is obviously a very political issue, we control for political orientation (10-point, left-right scale). Finally, we include a measure for whether the subject regularly participates at sports competitions.

We run OLS regressions for eight dependent variables: the degree of fatalism, the supply of redistribution in the DDG, the normalized importance levels given to each redistribution system in the RSG and the associated absolute importance levels. Using the best selection method, we present different specifications, which progressively include additional independent variables, based on their explanatory power. We impose that our specifications include the overachiever status and two dummies for the GAP sessions (i.e., session 3 to 6 ) and a dummy for EXTENDED to control for differences between the two versions of the control questions. The best selection method then includes additional variables according to their explanatory power. We present the C, the AICC and the BIC statistics. Tables A1 and A2 display the results for the Fatalism and RedSupply variables respectively. Tables A3, A4 and A5 display estimates of the normalized importance scores (Libert, SocialLib, Egal). Tables A6, A7 and A8 show respectively the results for absLibertarian, absSocialLib and absEgalitarian.

In the main article we take the stand that data analyzed in the paper are independent at the subject level. When participants make the essential decisions (Fatalism, RedSupply, and the scores in the RSG), they have had very limited information about other participants' behaviors. In particular, when answering the questions determining the Fatalism score, participants knew only their relative position in the group. When choosing on the redistribution in the DDG, they learned only the difference of payoffs between the two targets. Finally, when choosing among redistribution systems in the RSG, participants knew only the two previous pieces of information plus their own profit at the end of the first game. It is thus not possible to infer other subjects' decisions about redistribution from the information received. ${ }^{19}$ For the models $1-5$ in the Tables A1 to A8 we assume that the observations are independent.

\footnotetext{
${ }^{19}$ Note that the two subjects in each session in the role of the target in the DDG might draw some inference about the redistribution choice of their dictator. However, even for them it is very difficult, because they only learn their final income, and not the change in the income due to the redistribution. All our results from the RSG hold if we exclude the targets from the analysis.
} 
For model 5 in all these Tables we also cluster the data to check whether our estimations are robust to the violation of independence. Since we ran six experimental sessions, the clustering of the standard errors can be made on six clusters only. Recent works in the econometric literature have investigated the properties of estimates with low numbers of clusters, and show that standard corrections underestimate the true standard errors. In order to deal with this issue, we use wild cluster bootstrapping to compute a robust $p$-value for our parameter of interest (overachiever). We follow the guidelines given by Cameron and Miler (2015).$^{20}$ In addition to the OLS results of model 5, we report three statistics derived from the wild-clustering for each regression. On the one hand, we present the Rademacher and Webb $p$-values associated with the treatment's effect. These statistics are calculated for the regressions including all covariates. They must be interpreted similarly the $p$-values of the statistical test associated to the null hypothesis for the overachiever variable (two-sided test). In other words, we claim that the overachiever variable has a significant impact when these $p$-values are below $5 \%$. On the other hand, we report the distributions of the Webb and Rademacher t-statistics from which we derived the $p$-values (Figures A1 to A8). Note that, in our case, the wild cluster bootstrap technique yields similar results to the non-clustered results.

\footnotetext{
${ }^{20}$ Cameron, A. C. \& Miller, D. L. (2015), 'A Practitioner's Guide to Cluster-Robust Inference', Journal of Human Resources 50(2), 317-372.
} 


\begin{tabular}{|c|c|c|c|c|c|}
\hline Model & 1 & 2 & 3 & 4 & 5 \\
\hline overachiever & $\begin{array}{l}-0.361^{* * *} \\
(0.119)\end{array}$ & $\begin{array}{l}-0.368^{* * *} \\
(0.120)\end{array}$ & $\begin{array}{l}-0.377^{* * *} \\
(0.121)\end{array}$ & $\begin{array}{l}-0.380^{* * *} \\
(0.122)\end{array}$ & $\begin{array}{l}-0.387^{* * *} \\
(0.123)\end{array}$ \\
\hline GAP & $\begin{array}{l}-0.195 \\
(0.127)\end{array}$ & $\begin{array}{l}-0.194 \\
(0.127)\end{array}$ & $\begin{array}{l}-0.204 \\
(0.128)\end{array}$ & $\begin{array}{l}-0.214 \\
(0.130)\end{array}$ & $\begin{array}{c}-0.222^{*} \\
(0.131)\end{array}$ \\
\hline male & & $\begin{array}{l}-0.0774 \\
(0.122)\end{array}$ & $\begin{array}{l}-0.0707 \\
(0.123)\end{array}$ & $\begin{array}{l}-0.107 \\
(0.131)\end{array}$ & $\begin{array}{l}-0.101 \\
(0.131)\end{array}$ \\
\hline sport & & & & $\begin{array}{l}0.0805 \\
(0.146)\end{array}$ & $\begin{array}{l}0.0817 \\
(0.146)\end{array}$ \\
\hline polit_orient & & & & $\begin{array}{l}-0.0220 \\
(0.0274)\end{array}$ & $\begin{array}{l}-0.0195 \\
(0.0279)\end{array}$ \\
\hline age & & & $\begin{array}{l}0.0104 \\
(0.0170)\end{array}$ & & $\begin{array}{l}0.00854 \\
(0.0174)\end{array}$ \\
\hline constant & $\begin{array}{l}1.427^{* * *} \\
(0.119)\end{array}$ & $\begin{array}{l}1.553^{* * *} \\
(0.233)\end{array}$ & $\begin{array}{l}1.319^{* * *} \\
(0.448)\end{array}$ & $\begin{array}{l}1.459^{* * *} \\
(0.464)\end{array}$ & $\begin{array}{l}1.250^{* *} \\
(0.631)\end{array}$ \\
\hline Observations & 144 & 144 & 144 & 144 & 144 \\
\hline R-squared & 0.075 & 0.078 & 0.081 & 0.084 & 0.085 \\
\hline $\mathrm{C}$ & & 1.999 & 3.544 & 5.241 & 7 \\
\hline $\mathrm{AICC}$ & & 317.515 & 319.22 & 321.11 & 323.10 \\
\hline $\mathrm{BIC}$ & & 328.96 & 333.45 & 338.11 & 342.82 \\
\hline Rademacher $p$-value & & & & & 0.035 \\
\hline Webb $p$-value & & & & & 0.013 \\
\hline
\end{tabular}




\begin{tabular}{|c|c|c|c|c|c|}
\hline Model & 1 & 2 & 3 & 4 & 5 \\
\hline overachiever & $\begin{array}{l}-0.130^{* * *} \\
(0.0423)\end{array}$ & $\begin{array}{l}-0.129^{* * *} \\
(0.0424)\end{array}$ & $\begin{array}{l}-0.127^{* * *} \\
(0.0426)\end{array}$ & $\begin{array}{l}-0.125^{* * *} \\
(0.0433)\end{array}$ & $\begin{array}{l}-0.125^{* * *} \\
(0.0440)\end{array}$ \\
\hline GAP & $\begin{array}{l}-0.0409 \\
(0.0448)\end{array}$ & $\begin{array}{l}-0.0372 \\
(0.0454)\end{array}$ & $\begin{array}{l}-0.0324 \\
(0.0461)\end{array}$ & $\begin{array}{l}-0.0312 \\
(0.0465)\end{array}$ & $\begin{array}{l}-0.0311 \\
(0.0467)\end{array}$ \\
\hline polit_orient & & $\begin{array}{l}0.00546 \\
(0.00942)\end{array}$ & $\begin{array}{l}0.00634 \\
(0.00955)\end{array}$ & $\begin{array}{l}0.00578 \\
(0.00981)\end{array}$ & $\begin{array}{l}0.00572 \\
(0.00990)\end{array}$ \\
\hline sport & & & $\begin{array}{l}-0.0312 \\
(0.0488)\end{array}$ & $\begin{array}{l}-0.0325 \\
(0.0492)\end{array}$ & $\begin{array}{l}-0.0313 \\
(0.0524)\end{array}$ \\
\hline age & & & & $\begin{array}{l}-0.00185 \\
(0.00699)\end{array}$ & $\begin{array}{c}-0.00191 \\
(0.00708)\end{array}$ \\
\hline male & & & & & $\begin{array}{l}-0.00314 \\
(0.0475)\end{array}$ \\
\hline constant & $\begin{array}{l}0.466^{* * *} \\
(0.0423)\end{array}$ & $\begin{array}{l}0.438^{* * *} \\
(0.0644)\end{array}$ & $\begin{array}{l}0.532^{* * *} \\
(0.160)\end{array}$ & $\begin{array}{l}0.579^{* *} \\
(0.238)\end{array}$ & $\begin{array}{l}0.582^{* *} \\
(0.244)\end{array}$ \\
\hline Observations & 132 & 132 & 132 & 132 & 132 \\
\hline R-squared & 0.074 & 0.076 & 0.079 & 0.080 & 0.080 \\
\hline $\mathrm{C}$ & & 1.476 & 3.074 & 5.004 & 7 \\
\hline $\mathrm{AICC}$ & & 5.915 & 7.687 & 9.845 & 12.107 \\
\hline $\mathrm{BIC}$ & & 16.97 & 21.43 & 26.24 & 31.12 \\
\hline Rademacher $p$-value & & & & & 0.015 \\
\hline Webb $p$-value & & & & & 0.010 \\
\hline
\end{tabular}

Table A2: OLS regression of RedSupply. Standard errors in parentheses. ${ }^{* * *} \mathrm{p} \leq 0.01,{ }^{* *}$ $0.01<\mathrm{p} \leq 0.05, * 0.05<\mathrm{p} \leq 0.10$ 


\begin{tabular}{|c|c|c|c|c|c|}
\hline Model & 1 & 2 & 3 & 4 & 5 \\
\hline overachiever & $\begin{array}{l}0.0213 \\
(0.0385)\end{array}$ & $\begin{array}{l}0.0292 \\
(0.0369)\end{array}$ & $\begin{array}{l}0.0326 \\
(0.0372)\end{array}$ & $\begin{array}{l}0.0346 \\
(0.0375)\end{array}$ & $\begin{array}{l}0.0352 \\
(0.0378)\end{array}$ \\
\hline GAP & $\begin{array}{l}0.0414 \\
(0.0472)\end{array}$ & $\begin{array}{l}0.0400 \\
(0.0451)\end{array}$ & $\begin{array}{l}0.0424 \\
(0.0453)\end{array}$ & $\begin{array}{l}0.0413 \\
(0.0454)\end{array}$ & $\begin{array}{l}0.0423 \\
(0.0460)\end{array}$ \\
\hline EXTENDED & $\begin{array}{l}0.0499 \\
(0.0472)\end{array}$ & $\begin{array}{l}0.0830^{*} \\
(0.0459)\end{array}$ & $\begin{array}{l}0.0850^{*} \\
(0.0461)\end{array}$ & $\begin{array}{l}0.0865^{*} \\
(0.0463)\end{array}$ & $\begin{array}{l}0.0866^{*} \\
(0.0465)\end{array}$ \\
\hline polit_orient & & $\begin{array}{l}0.0318^{* * *} \\
(0.00845)\end{array}$ & $\begin{array}{c}0.0307^{* * *} \\
(0.00858)\end{array}$ & $\begin{array}{l}0.0311^{* * *} \\
(0.00864)\end{array}$ & $\begin{array}{l}0.0313^{* * *} \\
(0.00875)\end{array}$ \\
\hline age & & & $\begin{array}{l}-0.00396 \\
(0.00531)\end{array}$ & $\begin{array}{l}-0.00366 \\
(0.00535)\end{array}$ & $\begin{array}{l}-0.00367 \\
(0.00537)\end{array}$ \\
\hline male & & & & $\begin{array}{l}0.0218 \\
(0.0381)\end{array}$ & $\begin{array}{l}0.0242 \\
(0.0406)\end{array}$ \\
\hline sport & & & & & $\begin{array}{l}-0.00799 \\
(0.0450)\end{array}$ \\
\hline constant & $\begin{array}{l}0.195^{* * *} \\
(0.0385)\end{array}$ & $\begin{array}{l}0.0336 \\
(0.0566)\end{array}$ & $\begin{array}{l}0.124 \\
(0.134)\end{array}$ & $\begin{array}{l}0.0795 \\
(0.155)\end{array}$ & $\begin{array}{l}0.100 \\
(0.194)\end{array}$ \\
\hline Observations & 144 & 144 & 144 & 144 & 144 \\
\hline R-squared & 0.028 & 0.118 & 0.121 & 0.124 & 0.124 \\
\hline $\mathrm{C}$ & & 2.907 & 4.356 & 6.032 & 8 \\
\hline $\mathrm{AICC}$ & & -20.70 & -19.07 & -17.17 & -14.93 \\
\hline $\mathrm{BIC}$ & & -6.465 & -2.076 & 2.551 & 7.488 \\
\hline Rademacher $p$-value & & & & & 0.164 \\
\hline Webb $p$-value & & & & & 0.146 \\
\hline
\end{tabular}

Table A3: OLS regression of Libert. Standard errors in parentheses. ${ }^{* * *} \mathrm{p} \leq 0.01,{ }^{* *}$ $0.01<\mathrm{p} \leq 0.05, * 0.05<\mathrm{p} \leq 0.10$ 


\begin{tabular}{|c|c|c|c|c|c|}
\hline Model & 1 & 2 & 3 & 4 & 5 \\
\hline overachiever & $\begin{array}{l}0.135^{* * *} \\
(0.0399)\end{array}$ & $\begin{array}{l}0.142^{* * *} \\
(0.0397)\end{array}$ & $\begin{array}{l}0.141^{* * *} \\
(0.0399)\end{array}$ & $\begin{array}{l}0.141^{* * *} \\
(0.0402)\end{array}$ & $\begin{array}{l}0.142^{* * *} \\
(0.0406)\end{array}$ \\
\hline GAP & $\begin{array}{l}-0.0664 \\
(0.0488)\end{array}$ & $\begin{array}{l}-0.0696 \\
(0.0484)\end{array}$ & $\begin{array}{l}-0.0692 \\
(0.0485)\end{array}$ & $\begin{array}{l}-0.0680 \\
(0.0491)\end{array}$ & $\begin{array}{l}-0.0676 \\
(0.0494)\end{array}$ \\
\hline EXTENDED & $\begin{array}{l}0.0265 \\
(0.0488)\end{array}$ & $\begin{array}{l}0.0312 \\
(0.0485)\end{array}$ & $\begin{array}{l}0.0243 \\
(0.0495)\end{array}$ & $\begin{array}{l}0.0243 \\
(0.0497)\end{array}$ & $\begin{array}{l}0.0246 \\
(0.0499)\end{array}$ \\
\hline male & & $\begin{array}{l}0.0757^{*} \\
(0.0404)\end{array}$ & $\begin{array}{l}0.0735^{*} \\
(0.0406)\end{array}$ & $\begin{array}{l}0.0763^{*} \\
(0.0432)\end{array}$ & $\begin{array}{l}0.0759^{*} \\
(0.0436)\end{array}$ \\
\hline polit_orient & & & $\begin{array}{l}-0.00650 \\
(0.00911)\end{array}$ & $\begin{array}{l}-0.00625 \\
(0.00923)\end{array}$ & $\begin{array}{c}-0.00642 \\
(0.00940)\end{array}$ \\
\hline sport & & & & $\begin{array}{c}-0.00952 \\
(0.0482)\end{array}$ & $\begin{array}{c}-0.00962 \\
(0.0484)\end{array}$ \\
\hline age & & & & & $\begin{array}{c}-0.000625 \\
(0.00576)\end{array}$ \\
\hline constant & $\begin{array}{l}0.431^{* * *} \\
(0.0399)\end{array}$ & $\begin{array}{l}0.307^{* * *} \\
(0.0769)\end{array}$ & $\begin{array}{l}0.344^{* * *} \\
(0.0925)\end{array}$ & $\begin{array}{l}0.368^{* *} \\
(0.154)\end{array}$ & $\begin{array}{l}0.383^{*} \\
(0.209)\end{array}$ \\
\hline Observations & 144 & 144 & 144 & 144 & 144 \\
\hline R-squared & 0.087 & 0.110 & 0.113 & 0.113 & 0.113 \\
\hline $\mathrm{C}$ & & 2.552 & 4.051 & 6.012 & 8 \\
\hline $\mathrm{AICC}$ & & -.412 & 1.269 & 3.471 & 5.735 \\
\hline $\mathrm{BIC}$ & & 13.824 & 18.264 & 23.193 & 28.150 \\
\hline Rademacher $p$-value & & & & & 0.015 \\
\hline Webb $p$-value & & & & & 0.008 \\
\hline
\end{tabular}

Table A4: OLS regression of SocialLib. Standard errors in parentheses. ${ }^{* * *} \mathrm{p} \leq 0.01,{ }^{* *}$ $0.01<\mathrm{p} \leq 0.05, * 0.05<\mathrm{p} \leq 0.10$ 


\begin{tabular}{|c|c|c|c|c|c|}
\hline Model & 1 & 2 & 3 & 4 & 5 \\
\hline overachiever & $\begin{array}{l}-0.156^{* * *} \\
(0.0406)\end{array}$ & $\begin{array}{l}-0.162^{* * *} \\
(0.0398)\end{array}$ & $\begin{array}{l}-0.172^{* * *} \\
(0.0394)\end{array}$ & $\begin{array}{l}-0.176^{* * *} \\
(0.0397)\end{array}$ & $\begin{array}{l}-0.177^{* * *} \\
(0.0400)\end{array}$ \\
\hline GAP & $\begin{array}{l}0.0251 \\
(0.0497)\end{array}$ & $\begin{array}{l}0.0261 \\
(0.0487)\end{array}$ & $\begin{array}{l}0.0302 \\
(0.0479)\end{array}$ & $\begin{array}{l}0.0276 \\
(0.0481)\end{array}$ & $\begin{array}{l}0.0252 \\
(0.0487)\end{array}$ \\
\hline EXTENDED & $\begin{array}{l}-0.0764 \\
(0.0497)\end{array}$ & $\begin{array}{l}-0.101^{* *} \\
(0.0496)\end{array}$ & $\begin{array}{l}-0.109^{* *} \\
(0.0489)\end{array}$ & $\begin{array}{l}-0.111^{* *} \\
(0.0490)\end{array}$ & $\begin{array}{l}-0.111^{* *} \\
(0.0492)\end{array}$ \\
\hline polit_orient & & $\begin{array}{l}-0.0240^{* * *} \\
(0.00913)\end{array}$ & $\begin{array}{l}-0.0257^{* * *} \\
(0.00899)\end{array}$ & $\begin{array}{l}-0.0245^{* * *} \\
(0.00915)\end{array}$ & $\begin{array}{l}-0.0249^{* * *} \\
(0.00926)\end{array}$ \\
\hline male & & & $\begin{array}{l}-0.0979^{* *} \\
(0.0401)\end{array}$ & $\begin{array}{l}-0.0948^{* *} \\
(0.0404)\end{array}$ & $\begin{array}{l}-0.100^{* *} \\
(0.0429)\end{array}$ \\
\hline age & & & & $\begin{array}{l}0.00426 \\
(0.00566)\end{array}$ & $\begin{array}{l}0.00430 \\
(0.00568)\end{array}$ \\
\hline sport & & & & & $\begin{array}{l}0.0176 \\
(0.0476)\end{array}$ \\
\hline constant & $\begin{array}{l}0.374^{* * *} \\
(0.0406)\end{array}$ & $\begin{array}{l}0.496^{* * *} \\
(0.0611)\end{array}$ & $\begin{array}{l}0.665^{* * *} \\
(0.0914)\end{array}$ & $\begin{array}{l}0.562^{* * *} \\
(0.164)\end{array}$ & $\begin{array}{l}0.517^{* *} \\
(0.206)\end{array}$ \\
\hline Observations & 144 & 144 & 144 & 144 & 144 \\
\hline R-squared & 0.110 & 0.152 & 0.187 & 0.191 & 0.191 \\
\hline $\mathrm{C}$ & & 8.604 & 4.701 & 6.137 & 8 \\
\hline $\mathrm{AICC}$ & & 1.480 & -2.398 & -.749 & 1.383 \\
\hline BIC & & 15.72 & 14.60 & 18.97 & 23.80 \\
\hline Rademacher $p$-value & & & & & 0.020 \\
\hline Webb $p$-value & & & & & 0.0126 \\
\hline
\end{tabular}

Table A5: OLS regression of Egal. Standard errors in parentheses. ${ }^{* * *} \mathrm{p} \leq 0.01,{ }^{* *}$ $0.01<\mathrm{p} \leq 0.05, * 0.05<\mathrm{p} \leq 0.10$ 


\begin{tabular}{|c|c|c|c|c|c|}
\hline Model & 1 & 2 & 3 & 4 & 5 \\
\hline overachiever & $\begin{array}{l}0.347 \\
(0.593)\end{array}$ & $\begin{array}{l}0.473 \\
(0.567)\end{array}$ & $\begin{array}{l}0.456 \\
(0.569)\end{array}$ & $\begin{array}{l}0.445 \\
(0.576)\end{array}$ & $\begin{array}{l}0.451 \\
(0.581)\end{array}$ \\
\hline GAP & $\begin{array}{l}0.771 \\
(0.727)\end{array}$ & $\begin{array}{l}0.750 \\
(0.693)\end{array}$ & $\begin{array}{l}0.698 \\
(0.701)\end{array}$ & $\begin{array}{l}0.697 \\
(0.703)\end{array}$ & $\begin{array}{l}0.701 \\
(0.708)\end{array}$ \\
\hline EXTENDED & $\begin{array}{l}-0.0625 \\
(0.727)\end{array}$ & $\begin{array}{l}0.463 \\
(0.706)\end{array}$ & $\begin{array}{l}0.470 \\
(0.708)\end{array}$ & $\begin{array}{l}0.463 \\
(0.712)\end{array}$ & $\begin{array}{l}0.466 \\
(0.715)\end{array}$ \\
\hline polit_orient & & $\begin{array}{l}0.504^{* * *} \\
(0.130)\end{array}$ & $\begin{array}{l}0.497^{* * *} \\
(0.131)\end{array}$ & $\begin{array}{l}0.494^{* * *} \\
(0.132)\end{array}$ & $\begin{array}{l}0.492^{* * *} \\
(0.135)\end{array}$ \\
\hline sport & & & $\begin{array}{l}0.359 \\
(0.648)\end{array}$ & $\begin{array}{l}0.395 \\
(0.691)\end{array}$ & $\begin{array}{l}0.393 \\
(0.693)\end{array}$ \\
\hline male & & & & $\begin{array}{l}-0.0961 \\
(0.620)\end{array}$ & $\begin{array}{l}-0.101 \\
(0.624)\end{array}$ \\
\hline age & & & & & $\begin{array}{c}-0.00699 \\
(0.0826)\end{array}$ \\
\hline constant & $\begin{array}{l}3.368^{* * *} \\
(0.593)\end{array}$ & $\begin{array}{l}0.805 \\
(0.869)\end{array}$ & $\begin{array}{l}-0.293 \\
(2.167)\end{array}$ & $\begin{array}{l}-0.238 \\
(2.204)\end{array}$ & $\begin{array}{l}-0.0671 \\
(2.992)\end{array}$ \\
\hline Observations & 144 & 144 & 144 & 144 & 144 \\
\hline R-squared & 0.012 & 0.109 & 0.111 & 0.111 & 0.111 \\
\hline $\mathrm{C}$ & & 2.333 & 4.031 & 6.007 & 8 \\
\hline $\mathrm{AICC}$ & & 766.10 & 768.00 & 770.22 & 772.49 \\
\hline $\mathrm{BIC}$ & & 780.34 & 784.99 & 789.94 & 794.90 \\
\hline Rademacher $p$-value & & & & & 0.432 \\
\hline Webb $p$-value & & & & & 0.446 \\
\hline
\end{tabular}

Table A6: OLS regression of absLibert. Standard errors in parentheses. ${ }^{* * *} \mathrm{p} \leq 0.01,{ }^{* *}$ $0.01<\mathrm{p} \leq 0.05, * 0.05<\mathrm{p} \leq 0.10$ 


\begin{tabular}{|c|c|c|c|c|c|}
\hline Model & 1 & 2 & 3 & 4 & 5 \\
\hline overachiever & $\begin{array}{l}1.181^{* *} \\
(0.518)\end{array}$ & $\begin{array}{l}1.227^{* *} \\
(0.521)\end{array}$ & $\begin{array}{l}1.175^{* *} \\
(0.526)\end{array}$ & $\begin{array}{l}1.185^{* *} \\
(0.528)\end{array}$ & $\begin{array}{l}1.178^{* *} \\
(0.532)\end{array}$ \\
\hline GAP & $\begin{array}{l}-0.562 \\
(0.635)\end{array}$ & $\begin{array}{l}-0.582 \\
(0.636)\end{array}$ & $\begin{array}{l}-0.618 \\
(0.638)\end{array}$ & $\begin{array}{l}-0.625 \\
(0.640)\end{array}$ & $\begin{array}{l}-0.638 \\
(0.648)\end{array}$ \\
\hline EXTENDED & $\begin{array}{l}-0.938 \\
(0.635)\end{array}$ & $\begin{array}{l}-0.908 \\
(0.636)\end{array}$ & $\begin{array}{l}-0.951 \\
(0.639)\end{array}$ & $\begin{array}{l}-0.897 \\
(0.652)\end{array}$ & $\begin{array}{l}-0.898 \\
(0.654)\end{array}$ \\
\hline male & & $\begin{array}{l}0.474 \\
(0.531)\end{array}$ & $\begin{array}{l}0.510 \\
(0.533)\end{array}$ & $\begin{array}{l}0.533 \\
(0.537)\end{array}$ & $\begin{array}{l}0.503 \\
(0.571)\end{array}$ \\
\hline age & & & $\begin{array}{l}0.0593 \\
(0.0739)\end{array}$ & $\begin{array}{l}0.0652 \\
(0.0753)\end{array}$ & $\begin{array}{l}0.0654 \\
(0.0756)\end{array}$ \\
\hline polit_orient & & & & $\begin{array}{l}0.0551 \\
(0.122)\end{array}$ & $\begin{array}{l}0.0525 \\
(0.123)\end{array}$ \\
\hline sport & & & & & $\begin{array}{l}0.0999 \\
(0.634)\end{array}$ \\
\hline constant & $\begin{array}{l}7.118^{* * *} \\
(0.518)\end{array}$ & $\begin{array}{l}6.345^{* * *} \\
(1.009)\end{array}$ & $\begin{array}{l}5.016^{* *} \\
(1.941)\end{array}$ & $\begin{array}{l}4.572^{* *} \\
(2.180)\end{array}$ & $\begin{array}{l}4.313 \\
(2.738)\end{array}$ \\
\hline Observations & 144 & 144 & 144 & 144 & 144 \\
\hline R-squared & 0.072 & 0.077 & 0.082 & 0.083 & 0.083 \\
\hline $\mathrm{C}$ & & 2.863 & 4.228 & 6.025 & 8 \\
\hline $\mathrm{AICC}$ & & 741.11 & 742.65 & 744.68 & 746.93 \\
\hline $\mathrm{BIC}$ & & 755.35 & 759.65 & 764.40 & 769.34 \\
\hline Rademacher $p$-value & & & & & 0.051 \\
\hline Webb $p$-value & & & & & 0.044 \\
\hline
\end{tabular}

Table A7: OLS regression of absSocialLib. Standard errors in parentheses. ${ }^{* * *} \mathrm{p} \leq 0.01,{ }^{* *}$ $0.01<\mathrm{p} \leq 0.05, * 0.05<\mathrm{p} \leq 0.10$ 


\begin{tabular}{|c|c|c|c|c|c|}
\hline Model & 1 & 2 & 3 & 4 & 5 \\
\hline overachiever & $\begin{array}{l}-2.250^{\text {*** }} \\
(0.590)\end{array}$ & $\begin{array}{l}-2.380^{* * *} \\
(0.584)\end{array}$ & $\begin{array}{l}-2.459^{* * *} \\
(0.579)\end{array}$ & $\begin{array}{l}-2.550^{* * *} \\
(0.580)\end{array}$ & $\begin{array}{l}-2.566^{* * *} \\
(0.585)\end{array}$ \\
\hline GAP & $\begin{array}{l}0.0625 \\
(0.723)\end{array}$ & $\begin{array}{l}0.118 \\
(0.713)\end{array}$ & $\begin{array}{l}0.134 \\
(0.704)\end{array}$ & $\begin{array}{l}0.0617 \\
(0.704)\end{array}$ & $\begin{array}{l}0.0357 \\
(0.712)\end{array}$ \\
\hline EXTENDED & $\begin{array}{l}-1.521^{* *} \\
(0.723)\end{array}$ & $\begin{array}{l}-1.605^{* *} \\
(0.713)\end{array}$ & $\begin{array}{l}-1.900^{* * *} \\
(0.719)\end{array}$ & $\begin{array}{l}-1.950^{* * *} \\
(0.717)\end{array}$ & $\begin{array}{l}-1.951^{* * *} \\
(0.719)\end{array}$ \\
\hline male & & $\begin{array}{l}-1.342^{* *} \\
(0.595)\end{array}$ & $\begin{array}{l}-1.435^{* *} \\
(0.590)\end{array}$ & $\begin{array}{l}-1.353^{* *} \\
(0.590)\end{array}$ & $\begin{array}{l}-1.411^{* *} \\
(0.628)\end{array}$ \\
\hline polit_orient & & & $\begin{array}{l}-0.278^{* *} \\
(0.132)\end{array}$ & $\begin{array}{c}-0.245^{*} \\
(0.134)\end{array}$ & $\begin{array}{l}-0.250^{*} \\
(0.135)\end{array}$ \\
\hline age & & & & $\begin{array}{l}0.116 \\
(0.0828)\end{array}$ & $\begin{array}{l}0.116 \\
(0.0831)\end{array}$ \\
\hline sport & & & & & $\begin{array}{l}0.195 \\
(0.697)\end{array}$ \\
\hline constant & $\begin{array}{l}6.146^{* * *} \\
(0.590)\end{array}$ & $\begin{array}{l}8.336^{* * *} \\
(1.132)\end{array}$ & $\begin{array}{l}9.899^{* * *} \\
(1.344)\end{array}$ & $\begin{array}{l}7.126^{* * *} \\
(2.396)\end{array}$ & $\begin{array}{l}6.620^{* *} \\
(3.009)\end{array}$ \\
\hline Observations & 144 & 144 & 144 & 144 & 144 \\
\hline R-squared & 0.126 & 0.157 & 0.183 & 0.195 & 0.195 \\
\hline $\mathrm{C}$ & & 8.418 & 6.012 & 6.078 & 8 \\
\hline $\mathrm{AICC}$ & & 774.09 & 771.77 & 771.98 & 774.18 \\
\hline $\mathrm{BIC}$ & & 788.32 & 788.77 & 791.71 & 796.59 \\
\hline Rademacher p-value & & & & & 0.000 \\
\hline Webb p-value & & & & & 0.004 \\
\hline
\end{tabular}

Table A8: OLS regression of absEgal. Standard errors in parentheses. ${ }^{* * *} \mathrm{p} \leq 0.01,{ }^{* *}$ $0.01<\mathrm{p} \leq 0.05,{ }^{*} 0.05<\mathrm{p} \leq 0.10$ 


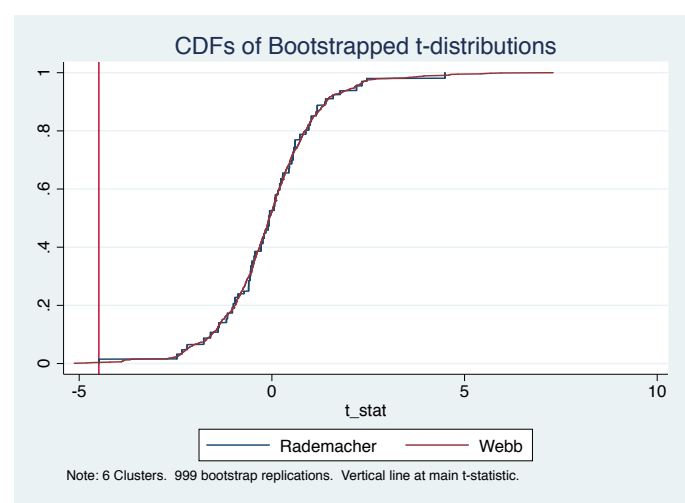

Figure A1: Distribution of the t-values using wild cluster-bootstrapping for $\mathrm{Fa}$ talism.

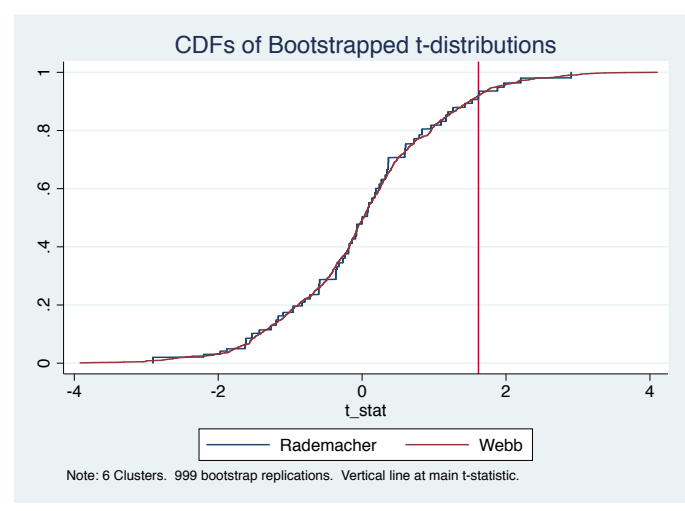

Figure A3: Distribution of the t-values using wild cluster-bootstrapping for Libert.

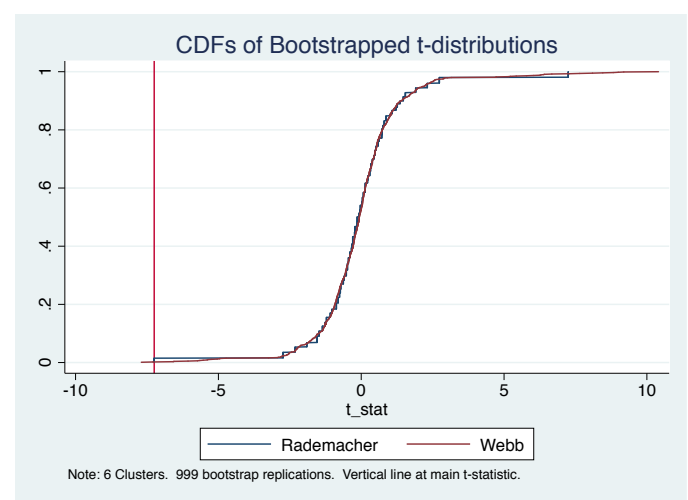

Figure A2: Distribution of the t-values using wild cluster-bootstrapping for RedSupply.

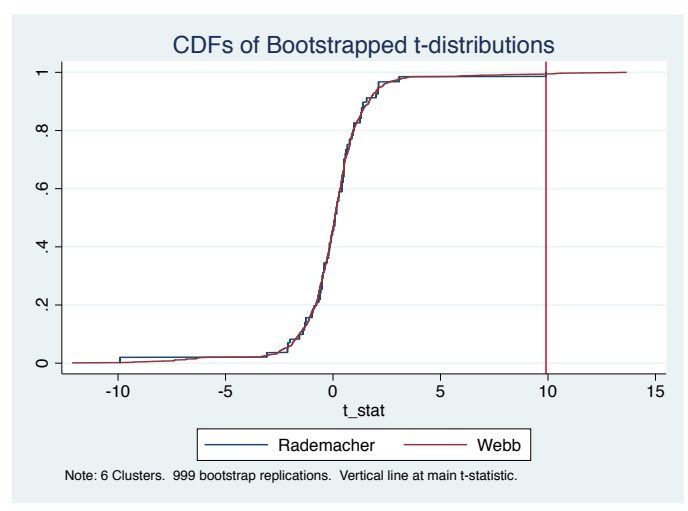

Figure A4: Distribution of the t-values using wild cluster-bootstrapping for $S o$ cialLib. 


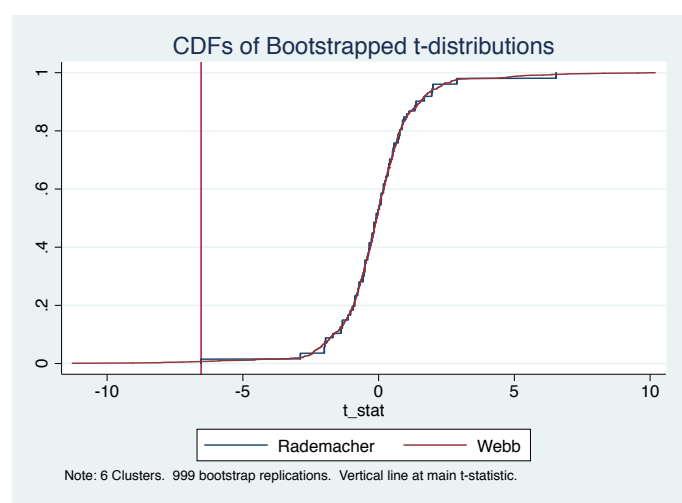

Figure A5: Distribution of the t-values using wild cluster-bootstrapping for Egal.

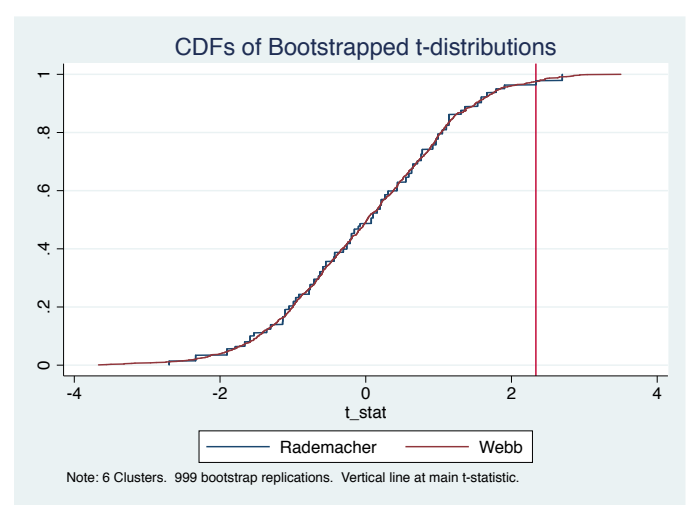

Figure A7: Distribution of the t-values using wild cluster-bootstrapping for $a b$ sSocialLib.

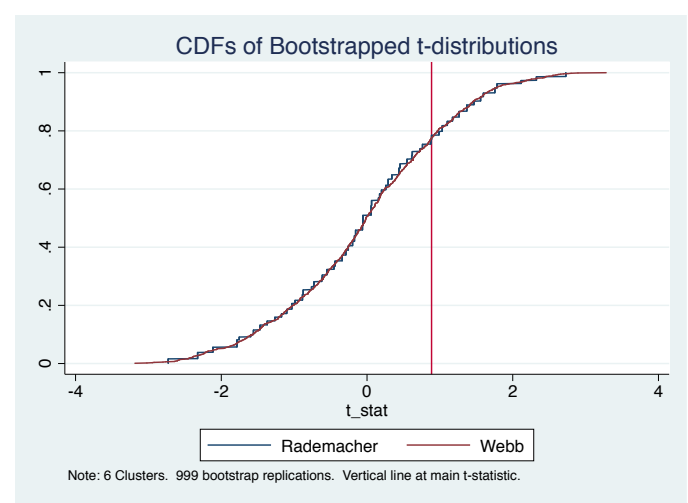

Figure A6: Distribution of the t-values using wild cluster-bootstrapping for $a b$ sLibert.

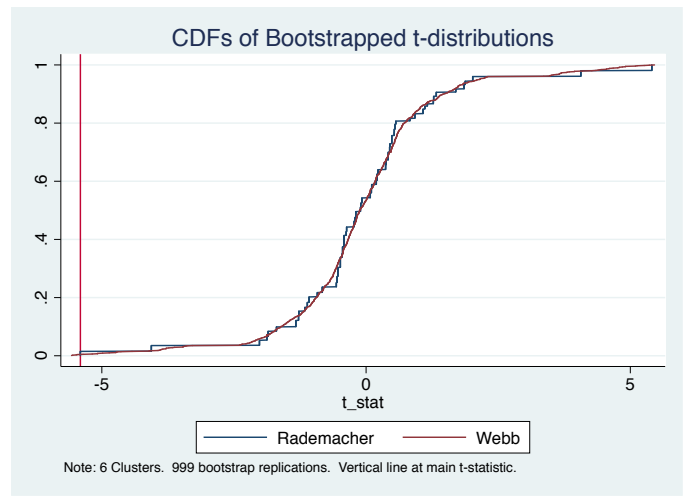

Figure A8: Distribution of the t-values using wild cluster-bootstrapping for $a b s E$ gal. 


\section{B Permutation Tests}

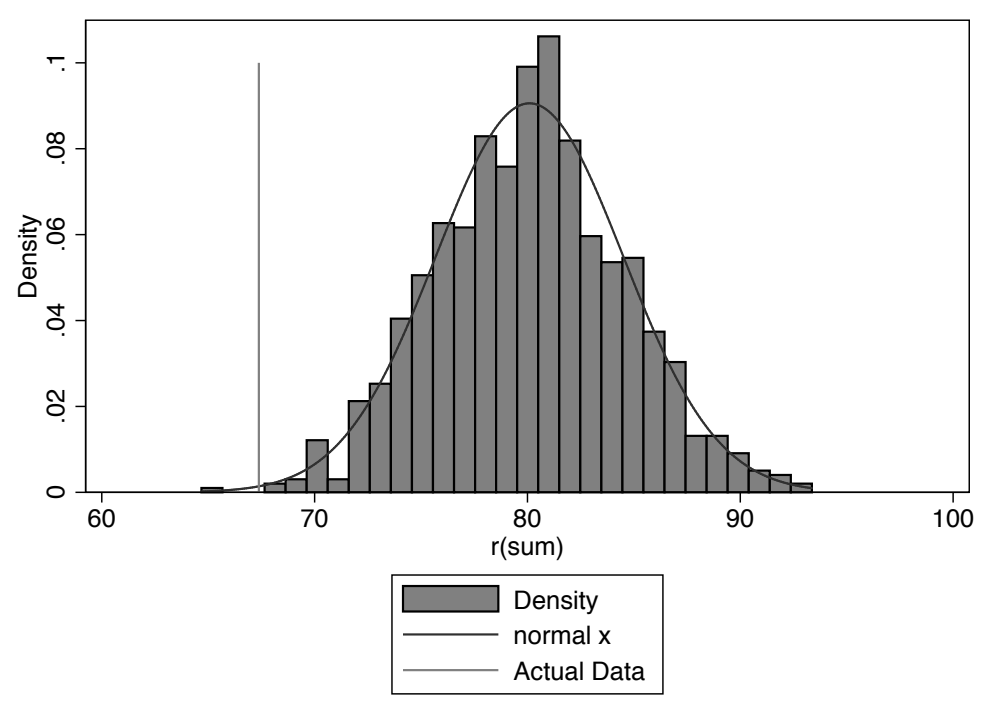

Figure B1: PDF of the permutation test for Fatalism.

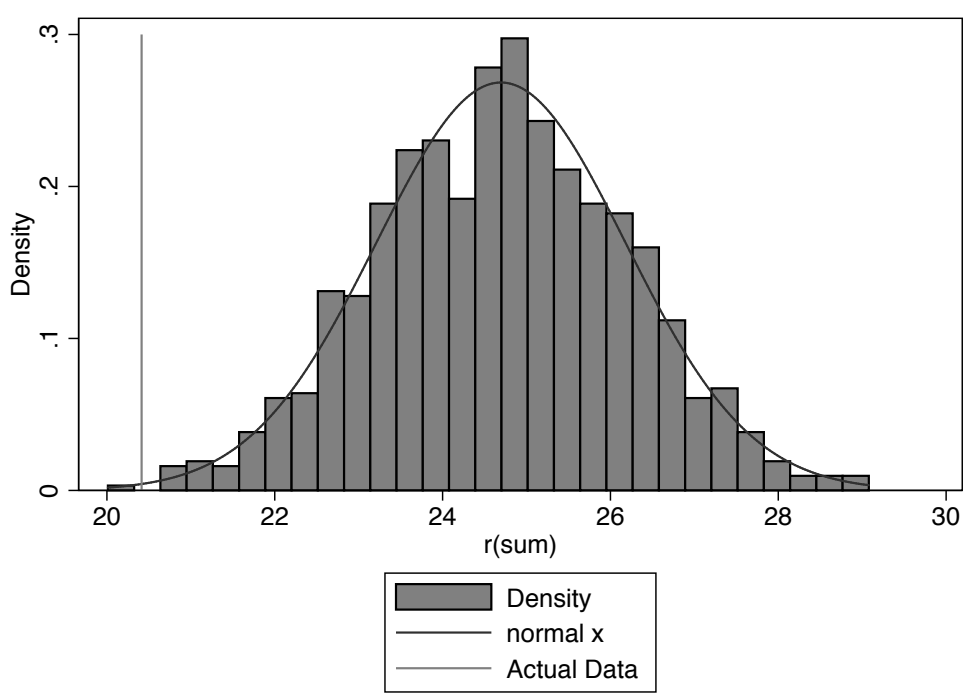

Figure B2: PDF of the permutation test for RedSupply. 


\section{Comparison of the STANDARD and GAP}

Our protocol contained two versions of the first real effort task: STANDARD (first two sessions) and the GAP (remaining four sessions). The difference between the two versions is the difference in the difficulty between the real effort tasks (the easy and the hard task). Compared to the STANDARD, the GAP task contained more simple easy tasks and more complex hard tasks, leading to a better separation of the profits in hard and easy.

As we have mentioned in the main text, in the STANDARD sessions the separation of subjects in over- and underachievers was not perfectly exogenous: four participants (three in the first session, one in the second session) in the hard task succeeded in performing better than the median and became overachievers. In GAP the task was perfectly separating in all sessions: participants who were assigned to the hard task became underachievers, while those who were assigned to the easy task turned out to be overachievers.

In Table C1 we compare overachievers and underachievers across versions of the experiment. As one can see, we observe no statistical difference across comparable groups at the 95\% confidence level, except for the absolute scores of the social-liberal system. Underachievers are less likely to allocate points to the social-liberal system in the GAP sessions. We also observe a similar decrease for overachievers although it is not significant. The resulting net effect is however not statistically significant, since the normalized scores are not affected by this decrease. Indeed, the absolute number of points for the egalitarian system also decreases for both groups (although not significant), which counterbalances the effect of the social-liberal system.

\begin{tabular}{lllllll}
\cline { 2 - 7 } & \multicolumn{3}{c}{ Overachievers } & \multicolumn{3}{c}{ Underachievers } \\
\cline { 2 - 7 } & $\begin{array}{l}\text { STANDARD } \\
(\text { mean })\end{array}$ & $\begin{array}{l}\text { GAP } \\
(\text { mean })\end{array}$ & $p$-value & $\begin{array}{l}\text { STANDARD } \\
(\text { mean })\end{array}$ & $\begin{array}{l}\text { GAP } \\
(\text { mean })\end{array}$ & $p$-value \\
\hline RedSupply & .329 & .299 & .64 & .474 & .422 & .419 \\
Fatalism & 1.017 & .895 & .213 & 1.476 & 1.207 & .257 \\
Libert & .202 & .29 & .123 & .209 & .254 & .452 \\
SocialLib & .565 & .513 & .446 & .431 & .377 & .284 \\
Egal & .233 & .197 & .537 & .36 & .368 & .892 \\
absLibert & 3.292 & 4.667 & .121 & 3.792 & 3.896 & .908 \\
absSocialLib & 7.875 & 7.479 & .61 & 7.542 & 5.875 & .038 \\
absEgal & 3.792 & 3.25 & .545 & 6.25 & 5.396 & .35 \\
\hline Table C1: Con
\end{tabular}

Table C1: Comparison of STANDARD and GAP versions of the experiment. P-values correspond to the two-group mean comparison tests. 


\section{Comparison of BASELINE and EXTENDED}

Our protocol contained two versions of instructions: BASELINE (first four sessions) and the EXTENDED (last two sessions). The difference between the two versions is the difference in the instructions given at the beginning of the second game. Compared to the BASELINE version, instructions of the EXTENDED version of the experiments were more detailed. Participants had more information about the nature and the magnitude of the random shocks, the example of the implementation of the redistribution system was more detailed, and the control questions before the vote required calculating various payoffs for different redistribution systems. Instructions of both versions of the experiment are displayed in Appendix E.

In Table D1 we compare the relative weight for the three redistributive systems for overachievers and underachievers across the two versions of the experiment (BASELINE vs. EXTENDED). Regarding the normalized scores we observe no significant differences across groups at the $95 \%$ confidence level. This implies that the participants' final decisions regarding the implemented redistribution system are not affected by the version of the experiment. Regarding the absolute scores we observe that both under- and overachievers are less fond of the social-liberal system in the EXTENDED version of the experiment. The difference is, however, only weakly significant for the overachievers $(p=.078)$. We also find that both types of participants tend to be less in favor of the egalitarian system in the EXTENDED version of the experiment. The decrease of support is only significant for the underachievers $(p=.042)$.

\begin{tabular}{lllllll}
\cline { 2 - 7 } & \multicolumn{3}{c}{ Overachievers } & \multicolumn{3}{c}{ Underachievers } \\
\cline { 2 - 7 } & $\begin{array}{l}\text { BASELINE } \\
\text { (mean) }\end{array}$ & $\begin{array}{l}\text { EXTENDED } \\
(\text { mean })\end{array}$ & $p$-value & $\begin{array}{l}\text { BASELINE } \\
(\text { mean })\end{array}$ & $\begin{array}{l}\text { EXTENDED } \\
(\text { mean })\end{array}$ & $p$-value \\
\hline Libert & .244 & .294 & .384 & .209 & .3 & .125 \\
SocialLib & .529 & .533 & .957 & .401 & .384 & .735 \\
Egal & .227 & .174 & .348 & .39 & .316 & .257 \\
absLibert & 4.229 & 4.167 & .944 & 3.625 & 4.333 & .43 \\
absSocialLib & 8.063 & 6.708 & .078 & 6.792 & 5.708 & .181 \\
absEgal & 3.813 & 2.667 & .198 & 6.292 & 4.458 & .042 \\
\hline
\end{tabular}

Table D1: Comparison of BASELINE and EXTENDED versions of the experiment; $p$-values from two-group mean comparison tests. 


\section{E Instructions and Screen Shots}

\section{E.1 Real effort task}

\section{First Part - Instructions}

Hello everyone!

You are about to take part to an experiment, and we are very thankful for your participation. This experiment is made of two parts. This instruction sheet refers to the first part of the experiment only. Instructions for the second part will be given to you at the end of this first part. If instructions turn to be unclear, or if a question remains unanswered, please raise your hand and wait for an instructor to come.

This experiment is made of both individual decisions and group interactions with other individuals in the room. At some points in the game, your decisions may affect others' payoffs, and reciprocally. For this reason, it is strictly forbidden to communicate during the entire experiment. In case of breach of this rule, we will be forced to expel you from the room.

During this experiment, you will earn ECU (Experimental Currency Unit). At the end of the experiment, the total number of ECU that you will have gained will be converted into EURO. The conversion rate is $5 \mathrm{ECU}$ for $1 \mathrm{EURO}$.

The first part of the experiment proceeds in several steps. First, you will be randomly assigned to a task. In this task, you will be asked to count the number of 1 in series of 0 and 1 . Your performance will be timed, and your gains will depend on the number of correct answers you will give. The assigned task will possibly be either easy (50\% chances) or hard $(50 \%$ chances). Both kinds of tasks contain the same number of ECU to win.

Example: 011010. This series of digits contains 3 ones. The correct answer is 3 .

Once all participants have completed their task, you will be asked to answer few questions. Then, two participants (the targets) will be randomly selected. The first part of the experiment will end at this point for the two targets. The remaining participants (the judges) will learn the difference of ECU between the two target participants, and will have the opportunity to transfer ECU from the wealthiest to the poorest participant.

Example: Participant A owns 8 ECU more than B. How many of these ECU are you willing to transfer to $B$ ? The answer must lie between 0 (no redistribution) and 8 (total transfer).

Once all judge participants have chosen a level of redistribution, a solution will be randomly drawn, and will be implemented for the two targets only. 
To sum up, the first part of the experiment unfolds as follows:

1) All participants are randomly assigned to a task;

2) All participants do their task;

3) Participants answer few questions;

4) Two participants are randomly selected (target participants);

5) The difference of ECU between the two targets is displayed to the judges who decide on the allocation these ECU;

6) One redistribution proposal is randomly selected

7) All participants learn their final payoff. It is equal to their performance to the task for the judges, and equal to the performance affected by the randomly selected redistribution solution for the targets. 


\section{E.2 RSG: BASELINE}

\section{Second Part - Instructions (BASELINE)}

The second part of the experiment is about to start. In this part, you will be asked to complete a series of tasks. These tasks are substantially different from what you have done in the first part of this experiment. Your profit for each task will depend on both your effort (the number of ECU received at the task) and a random component (a positive or negative shock).

At the beginning of this part, you will be randomly grouped with 3 other participants. Oncethegroupisformed, It will remain identical until the end of the experiment. Before the beginning of the second task, your group will be asked to choose a redistribution rule. The retained redistribution rule will be implemented after each task: it will determine the way to reallocate the sum of all profits made by the group at each period. Note that tasks are played individually.

You will be asked to choose among the three following redistribution systems:

1) The libertarian rule corresponds to a situation without redistribution: each participant keeps the ECU he obtained at each task.

2) The egalitarian rule corresponds to a situation with full redistribution: all ECU obtained by the group members are reallocated in equal shares among group members.

3) The social-liberal corresponds to a situation with partial redistribution: all ECU obtained by the group members are reallocated proportionally to individual efforts.

Each participant will be asked to decide on the importance he wants to give to each of the three systems presented above to define the group redistribution system. One solution among the group members will then be randomly selected and implemented for the group until the end of the experiment.

Example: One group of four participants obtained the following outcome at the assigned task: participant $A, B$ and $C$ obtained 4 ECU, while participant D, obtained 6 ECU. After a random shock participant A obtains 3 ECU and B, C and D obtain 5 ECU each.

\begin{tabular}{|l|l|l|l|l|l|}
\hline Participant & $\begin{array}{l}\text { Number of } \\
\text { ECU } \\
\text { obtained at } \\
\text { the task }\end{array}$ & $\begin{array}{l}\text { Number of } \\
\text { ECU after } \\
\text { the shock }\end{array}$ & $\begin{array}{l}\text { Payoff if full } \\
\text { libertarian } \\
\text { redistribution } \\
\text { system }\end{array}$ & $\begin{array}{l}\text { Payoff if full } \\
\text { social-liberal } \\
\text { redistribution } \\
\text { system }\end{array}$ & $\begin{array}{l}\text { Payoff if full } \\
\text { egalitarian } \\
\text { redistribution } \\
\text { system }\end{array}$ \\
\hline$A$ & 4 & 3 & 3 & 4 & 4.5 \\
\hline$B$ & 4 & 5 & 5 & 4 & 4.5 \\
\hline$C$ & 4 & 5 & 5 & 4 & 4.5 \\
\hline$D$ & 6 & 5 & 5 & 6 & 4.5 \\
\hline
\end{tabular}




\section{E.3 RSG: EXTENDED}

\section{Second Part - Instructions (EXTENDED)}

The second part of the experiment is about to start. In this part, you will be asked to complete a series of tasks. These tasks are substantially different from what you have done in the first part of this experiment. Your profit for each task will depend on both your effort (the number of ECU received at the task) and a random component (a positive or negative $c h o c$ ). Each task can give you individually $0,4,8,12,16$ or 20 ECU. Individual shocks may affect your own payoff by the following amounts: $-5,-4,-3,-2,-1$, $0,+1,+2,+3,+4,+5$ (all shocks have the same probability of occurrence). Shocks affecting other participants of your group are independent of the shock that affect your own payoff.

At the beginning of this part, you will be randomly grouped with 3 other participants. Once the group is formed, it will remain identical until the end of the experiment. Before the beginning of the second task, your group will be asked to choose a redistribution rule. The retained redistribution rule will be implemented after each task: it will determine the way to reallocate the sum of all profits made by the group at each period. Note that tasks are played individually.

You will be asked to choose among the three following redistribution systems:

1) The libertarian rule corresponds to a situation without redistribution: each participant keeps the ECU he obtained at each task and after the shock affected him.

2) The egalitarian rule corresponds to a situation with full redistribution: all ECU obtained by the group members after the individual shocks are reallocated in equal shares among group members.

3) The social-liberal system corresponds to a situation with partial redistribution: all ECU obtained by the group members after the individual shocks are reallocated proportionally to individual efforts (i.e. according to the individual pre-shock payoffs).

Each participant will be asked to decide on the importance he wants to give to each of the three systems presented above to define the group redistribution system. You will be able to give a score ranging from 0 to 10 to each of the three systems. These scores will define a redistribution system. For instance, if you allocate 8 points to each system, the corresponding redistribution rule will be made of $1 / 3$ (one third) of the libertarian system, $1 / 3$ of the egalitarian system, and $1 / 3$ of the social-liberal system. If you decide to unequally weight the three systems, the resulting system will be proportional to the allocated scores. For example, if you allocate 8 points to the libertarian system, 4 points to the egalitarian system, and 0 point to the social-liberal system, the resulting redistribution system will be made of $2 / 3$ (two thirds) of the libertarian system and $1 / 3$ of the egalitarian system.

Once all group members will have made their choice, one and only one solution among the group members will be randomly drawn and implemented for the group until the end of the experiment. For instance, if one of your group member chose $20 \%$ of the libertarian system, $50 \%$ of the egalitarian system, and $30 \%$ of the social-liberal system, and that his/her solution has been selected to be implemented, the redistribution that will occur after each task will be made in the following proportions: $20 \%$ of the aftershock payoff will not be modified (20\% libertarian), $50 \%$ will be redistributed equally 
( $50 \%$ egalitarian), and $30 \%$ will be redistributed proportionally to the pre-shock payoff (30\% social-liberal).

Example: One group of four participants obtained the following outcomes at the assigned task: participant $A, B$ and $C$ obtained 4 ECU each, while participant $D$ obtained $6 E C U$ (second column in the table below). After a random shock, participant A obtains 3 ECU, B and D obtain 5 ECU each, and Cobtains 7 points (third column).

In the libertarian system, each individual keeps his/her own after-shock payoff. Individual A would therefore keep his/her 3 ECU (fourth column). In the egalitarian system, all individuals receive the same share of the total after-shock revenue, i.e. one fourth of 20 ECU. Individual A would therefore receive 5 ECU (fifth column). In the social-liberal system, participants receive a share proportional to their pre-shock payoff. Individual A received 4 ECU prior to the shock and the group totalized 18 ECU. The total revenue after the shock is 20 ECU. Using a rule of three, the payoff of individual $A$ in a social-liberal system would be equal to: $(4 / 18) * 20=4.5$ (rounded at 0.5) (sixth column).

\begin{tabular}{|l|c|c|c|c|c|}
\hline Participant & $\begin{array}{l}\text { Number of } \\
\text { ECU } \\
\text { obtained } \\
\text { at the task }\end{array}$ & $\begin{array}{l}\text { Number of } \\
\text { ECU after } \\
\text { the shock }\end{array}$ & $\begin{array}{l}\text { Payoff if full } \\
\text { libertarian } \\
\text { redistribution } \\
\text { system }\end{array}$ & $\begin{array}{l}\text { Payoff if full } \\
\text { egalitarian } \\
\text { redistribution } \\
\text { system }\end{array}$ & $\begin{array}{l}\text { Payoff if full } \\
\text { social- } \\
\text { liberal } \\
\text { redistribution } \\
\text { system }\end{array}$ \\
\hline A & 4 & 3 & $\underline{\mathbf{3}}$ & $\underline{\mathbf{5}}$ & $\underline{\mathbf{4 . 5}}$ \\
\hline B & 4 & 5 & 5 & 5 & 4.5 \\
\hline C & 4 & 7 & 7 & 5 & 4.5 \\
\hline D & 6 & 5 & 5 & 20 & 6.5 \\
\hline Somme & 18 & 20 & 20 & & 20 \\
\hline
\end{tabular}

Imagine that the system that has been randomly selected to be implemented is as described in the above example: $20 \%$ libertarian, $50 \%$ egalitarian, and $30 \%$ social-liberal. The afterredistribution payoffs of individuals $A, B, C$ and $D$ are given in the table below. Participant A's final payoff is computed by taking $20 \%$ of his/her libertarian payoff $(0,20 * 3)$ (see above table), $50 \%$ of his/her egalitarian payoff $(0,50 * 5)$, and $30 \%$ of his/her social-liberal payoff $(0,30 * 4.5)$.

\begin{tabular}{|l|l|c|}
\hline Participant & $\begin{array}{l}\text { Number of ECU after redistribution (before } \\
\text { rounding) }\end{array}$ & $\begin{array}{l}\text { Final payoff } \\
\text { (rounded) }\end{array}$ \\
\hline$A$ & $20 \% * \underline{\mathbf{3}}+50 \% * \underline{\mathbf{5}}+30 \% * \underline{\mathbf{4}, \mathbf{5}}=0.6+2.5+1.35=4.45$ & 4 \\
\hline$B$ & $20 \% * 5+50 \% * 5+30 \% * 4,5=1+2.5+1.35=4.85$ & 5 \\
\hline$C$ & $20 \% * 7+50 \% * 5+30 \% * 4,5=1.4+2.5+1,35=5.25$ & 5 \\
\hline$D$ & $20 \% * 5+50 \% * 5+30 \% * 6,5=1+2.5+1.95=5.45$ & 5 \\
\hline
\end{tabular}




\title{
E.4 Screenshots
}

\begin{abstract}
You have been selected as a third-party to redistribute ECU between two participants. Although they might not have faced the same task, the two participants were randomly selected to possibly be targeted by redistribution. So far, participant A owns 20 ECU more than
\end{abstract} participant B

How would you like to allocate these additional ECU owned by participant $A$ ?

(Note that your decision will not impact your own profit, and that you will not be subject to redistribution during this stage of the experiment.)

Number of ECU left to A:

Number of ECU transferred to $B$ :

Figure E1: Screen Shot: Redistribution Decision in the Disinterested Dictator Game

\begin{tabular}{c|c|c|c|c|c|c|} 
Before voting on redistribution rules, a small exercise to insure that the systems are clear. Complete the following \\
table according to the redistribution rules. (You can access the calculator by clicking on the icon on the bottom-right \\
of the screen.)
\end{tabular}

Figure E2: Screen Shot: Control question for the RSG in the ExTENDED version. Participants first calculate the payoffs for $100 \%$ libertarian, and then continue with the profits of the other systems. 